Artigo original

Hegemonia - Revista Eletrônica de Relações Internacionais do Centro Universitário Unieuro

ISSN: $1809-1261$

UNIEURO, Brasília, número 15, 2015, pp. 42-92.

Recebido em: 2/3/2015

Avaliado em:18/5/2015

Aprovado em: 10/6/2015

\title{
Justiça de Transição no Brasil: Cenário Atual e Projetos Políticos de Mudanças - Análise de Fontes Primárias e Secundárias
}

Alessandro Rodrigues da Costa ${ }^{1}$

RESUMO: O presente artigo pretende interpretar, a partir de fontes primárias e secundárias, o que declaram os agentes que participam diretamente de discussões que podem efetivamente mudar os rumos que a Justiça de Transição vem tomando no Brasil até aqui. Tratamse de congressistas envolvidos em projetos de Lei que tem por objeto a revisão da Lei de Anistia, bem como de membros da Comissão Nacional da Verdade, cujo relatório final de seus trabalhos pode influenciar também em maior empenho para que esses projetos tramitem com maior celeridade nas casas legislativas e eventualmente, tenham chances reais de aprovação. Nesse mister, convém ressaltar 0 alcance limitado quanto aos trabalhos desenvolvidos pela Comissão Nacional da Verdade, que impede que haja solicitação para indiciamentos e, consequentemente, que os agentes que agiram em nome do Estado ditatorial sejam responsabilizados pelas torturas, desaparecimentos e assassinatos ocorridos durante o regime militar caminha, também, para manter no Brasil uma Justiça de Transição incompleta, levando ao problema cerne dos apontamentos aqui realizados no sentido de que essa incompletude lança dúvidas sobre se a CNV poderá atingir seu objetivo, previsto na Lei que a criou, de promover a reconciliação nacional.

Doutorando em Ciências Sociais pela Universidade de Brasília. 
Artigo original

Hegemonia - Revista Eletrônica de Relações Internacionais do Centro Universitário Unieuro

ISSN: $1809-1261$

UNIEURO, Brasília, número 15, 2015, pp. 42-92.

Palavras-chave: anistia; justiça de transição; memória; democracia; reconciliação nacional.

ABSTRACT: This article seeks to interpret, from primary and secondary sources, which state agents who directly participate in discussions that can effectively change the direction that the Transitional Justice in Brazil has been taking so far. These are congressmen involved in projects that Act's purpose is to review the Amnesty Act, as well as members of the National Truth Commission, whose final report of their work can also influence a greater commitment to these projects with greater tramitem expedite the legislative houses and eventually, have a real chance of approval. In this mister, it is worth emphasizing the limited scope as the work developed by the National Truth Commission, which ensures that there is request for indictments and, consequently, that the agents who acted on behalf of the dictatorial state accountable for torture, disappearances and killings during the military regime also walks to keep in Brazil, a Justice of incomplete transition, leading to the core issue of notes held here in the sense that this incompleteness casts doubt on whether the CNV can achieve your goal, under Law that created, to promote national reconciliation.

Keywords: amnesty; transitional justice; memory; democracy; national reconciliation.

\section{A JUSTIÇA DE TRANSIÇÃO NO ESTADO DEMOCRÁTICO DE DIREITO: REQUISITOS E ELEMENTOS}

O termo "Justiça de Transição" não expressa uma definição acabada, mas uma forma recente de tentar descrever uma justiça adaptada a sociedades que estão atravessando ou que recentemente atravessaram situações extremas de violência ou conflito, cuja profundidade de suas marcas foram tão indeléveis que afetaram a estabilidade política e social que fundavam a vida em comum. ${ }^{2}$

Conforme definição do International Center for Transitional Justice (ICTJ), não se trata de um tipo peculiar de justiça, mas de uma justiça adaptada a um determinado contexto: "a justiça de transiçãoo não é uma forma especial de justiå, 
Artigo original

Hegemonia - Revista Eletrônica de Relações Internacionais do Centro Universitário Unieuro

ISSN: $1809-1261$

UNIEURO, Brasília, número 15, 2015, pp. 42-92.

Para Abrão (2011, p. 215) Justiça de Transição é o modelo de justiça que tem como objetivo a promoção da reconciliação da nação com o seu próprio passado de violações e abusos.

Para Santos (2010, p. 129) a Justiça de Transição é um conjunto de medidas estabelecidas durante ou após a mudança de regimes autoritários para regimes democráticos, ou ainda, em períodos pós-guerra, pós-violência ou pós-conflito.

Dessa forma, visualiza-se o conceito de Justiça de Transição naquele contexto em que, findo um conflito civil ou mesmo, para ser atual, reiterado ataque terrorista em determinado Estado, necessário que haja uma política de ações voltadas à retomada do convívio pacífico dentre aqueles nacionais, visando manter a legalidade e a ordem no Estado.

Conforme Piovesan (2012, p. 212), não há dúvidas de que os pressupostos da Justiça de Transição, direito à memória e à verdade, direito à justiça, direito de reparação e reformas institucionais estão entrelaçados, sendo que, a concretização de um pressuposto, depende do avanço do outro.

A Justiça de Transição lança o delicado desafio de como romper com o passado autoritário e viabilizar o ritual de passagem à ordem democrática, corrompendo-a com as marcas de um continuísmo autoritário. Justiça e paz, justiça

mas a justiça adaptada a sociedade em transformaçãoo após um período de profundos abusos contra os direitos humanos. Em alguns casos, essas transformações acontecem reprentinamente; em outras, elas podem ocorrer ao longo de décadas: No original "Transitional justice is not a especial formo f justice but justice adapted to societies transforming themselves after a period of pervasieve human rights abuse. In some cases, these transformations happen suddenly, in other, they may take place over many deades". Disponível em . Acesso em 12.3.2013. 
Artigo original

Hegemonia - Revista Eletrônica de Relações Internacionais do Centro Universitário Unieuro

ISSN: $1809-1261$

UNIEURO, Brasília, número 15, 2015, pp. 42-92.

sem paz; e paz sem justiça são os dilemas da transição democrática. (PIOVESAN, 2012, p. 212).

Assim, de acordo com estudos sobre diversos países que passaram por períodos de exceção e tiveram, posteriormente implantadas políticas de transição para a democracia, são três os elementos fundamentais para a completa e bem sucedida justiça transacional: a memória, assim entendida por Pinto (2012, p. 25), como "um processo cultural, educativo e social de construção de consensos e de identidade nacional", a verdade, vislumbrada no caso do período militar com a efetiva publicidade de documentos até então protegidos pelo sigilo oficial ou extra-oficial, bem como através da realização de debates, fóruns e seminários sobre os abusos praticados pelos agentes estatais durante a ditadura, e por fim, a responsabilização (justiça e reparação), que, segundo Pinto (2012, p. 25) "envolve não apenas prisões ou penas pecuniárias, mas principalmente a conscientização do agressor acerca da gravidade de seus atos e a divulgação de seus nomes perante a comunidade."

Sobre esses três eixos, portanto, abarca-se a investigação dos crimes cometidos contra os direitos humanos; a reparação civil das vítimas e/ou seus familiares; o julgamento dos agentes que praticaram essas violações; a reforma do judiciário e das instituições de segurança como meio de evitar a repetição dos ilícitos, bem como as políticas que visem preservar a memória e as experiências vividas pelas vítimas.

Não havendo a completude dos elementos recém citados, mostra-se incompleto qualquer tentativa de se instituir processo de Justiça de Transição, como é o caso apresentado no Brasil.

Nos próximos itens, estão apresentados com maior detimento os elementos integrantes da Justiça de Transição, bem como a fundamentação que ampara a importância de cada um deles no processo de reconciliação nacional. 
Artigo original

Hegemonia - Revista Eletrônica de Relações Internacionais do Centro Universitário Unieuro

ISSN: $1809-1261$

UNIEURO, Brasília, número 15, 2015, pp. 42-92.

\section{A IMPORTÂNCIA DO DIREITO À MEMÓRIA E À VERDADE}

A memória e a verdade mostram-se como elementos inescapáveis à completa Justiça de Transição. A memória é muito mais do que apenas trazer à mente informações vividas em algum momento anterior. De acordo com Foster (2011, p. 8), "sempre que a experiência de um evento passado influencia alguém em um momento futuro, a influência dessa experiência anterior é uma elaboração da memória sobre o acontecimento passado."

O resgate da memória de algo que aconteceu, trás consigo o fato de que esse "algo", ou seja, o fato ocorrido, ainda é importante, pela própria razão de merecer ser resgatado. Dessa forma, a memória mostra-se como instrumento eficaz para adquirir, armazenar e recuperar informações.

É possível também distorcer a narrativa visando falsear os fatos ao interesse de governos ditatoriais, o que se configura como um abuso da memória coletiva, ganhando assim, um aspecto negativo.

Nas palavras de Ricouer (2007, p. 82) há três formas negativas de se fazer uso da memória: "a memória enferma (referente a traumas tendentes a serem esquecidos), a memória manipulada (utilizada para se alterar a identidade de um povo) e a memória obrigada (refere-se a uma memória forçada, imposta, em especial por um governo à sua população".

Dessa forma, uma sociedade desprovida de memória ou, ainda, com memórias negativas, como por exemplo no caso das ditaduras, tende a favorecer a alienação. De outro lado, os atos negativos do passado, presentes na memória coletiva, tendem a causar furor, inquietação, unindo a coletividade (a sociedade) que foi vítima daqueles atos (torturas, guerras, violações de direitos humanos fundamentais) de modo a exigir seus direitos e evitar que o passado de abusos se repita. 
Artigo original

Hegemonia - Revista Eletrônica de Relações Internacionais do Centro Universitário Unieuro

ISSN: $1809-1261$

UNIEURO, Brasília, número 15, 2015, pp. 42-92.

Ao se fazer, portanto, uso da memória ligada ao período da ditadura no Brasil, das violações e abusos dela resultantes, propiciase ambiente favorável à construção de um futuro diferente, como se pode vislumbrar pelas garantias individuais insertas na Carta Magna de 1988, imediatamente posterior aos 21 anos de regime militar.

Segundo Ricouer (2007, p. 423) "no esquecimento há o problema de memória da fidelidade ao passado" e, ainda no mesmo trecho "no perdão há a reconciliação com o passado, assim, contra o esquecimento é necessário fazer uso da memória e do perdão".

Nessa linha, paradoxalmente o esquecimento torna-se essencial para o armazenamento eficaz da memória. Para Ricouer (2007, p. 423), "se a memória nos liga ao passado, o perdão, por sua vez nos desliga dele". O perdão torna-se, pois, instrumento útil para que a sociedade possa se livrar do passado penoso, libertando-se, desse modo, do ciclo de vingança e de luto, sendo este o discurso utilizado por muitos governos e por diversas comissões da verdade, em especial, como exemplo categórico, a instituída na África do Sul, por ocasião do fim do apartheid naquele país.

De fato muitos estudiosos e cientistas políticos afirmam que o perdão pode ser a forma mais correta para se alcançar a reconciliação, uma vez que há culpados tanto entre as vítimas do regime como, evidentemente, dos agentes que atuaram em nome do Estado. Segundo essa corrente vigora a máxima de que o perdão liberta o passado e a promessa orienta o futuro, indicando-Ihe uma justa direção.

No Brasil, o discurso dos militares para tomarem de assalto o poder foi o de "impedir um golpe dos comunistas", no que foi amplamente apoiada pela sociedade civil, desiludida pelo fracasso do plano trienal de João Goulart.

A fim de garantir a sustentabilidade política, diversos atos institucionais foram expedidos pelo regime militar que, durante muito tempo manteve a aprovação principalmente da classe média, amparado pelo chamado "Milagre Econômico". 
Artigo original

Hegemonia - Revista Eletrônica de Relações Internacionais do Centro Universitário Unieuro

ISSN: $1809-1261$

UNIEURO, Brasília, número 15, 2015, pp. 42-92.

O AI 5 impôs à população brasileira uma total insegurança jurídica, uma vez que não havia para esta um mínimo de proteção estatal, sendo que a qualquer instante, qualquer cidadão poderia ser preso e interrogado, sem aviso aos entes familiares, nem direito a advogado, por tempo indeterminado.

Havia, é claro, um ingrediente ainda mais perverso: a tortura. Prática insistentemente negada ao longo do tempo pelos agentes do regime militar, sob a argumentação de que, se existiu, foi em mínima escala e, ainda assim, praticada por recrutas de patente inferior e sem o conhecimento dos seus superiores.

Os acontecimentos que possibilitaram as violações aos direitos humanos, a derrubada de instituições, a imposição de medidas que desmantelam uma sociedade por idéias ditatoriais quando devidamente resgatados pela memória são capazes de unir uma sociedade e a produzir novos valores na construção de sua identidade, pois as violações ocorridas no passado vão possibilitar as garantias a e justiça do hoje.

A memória é um direito fundamental do indivíduo. É função do Direito atuar neste campo como o grande produtor de normas e garantias de prerrogativas individuais, de também evoluir com a sociedade na instituição de espaços próprios a possibilitar debates e a existência de mecanismos hábeis a sempre preservar a memória e oferecer à sociedade atual e do futuro as bases para que sua história tenha um sentido positivo e impossibilitar novas transgressões.

$\mathrm{Na}$ atuação do Direito como forma de instituir, encontra-se a figura da Justiça de Transição (JT), entre um regime ditatorial para um democrático, traduzida no conjunto de abordagens, medidas e estratégias que possibilitam enfrentar o legado da violência existente no passado para gerar uma responsabilidade, exigir efetividade do direito à memória e à verdade, fortalecer as instituições com valores democráticos, a punição dos culpados, a criação de Comissões da Verdade, a reparação dos prejuízos sofridos pelas vítimas. 
Artigo original

Hegemonia - Revista Eletrônica de Relações Internacionais do Centro Universitário Unieuro

ISSN: $1809-1261$

UNIEURO, Brasília, número 15, 2015, pp. 42-92.

O conceito e as regras para a JT foram criados no âmbito das Nações Unidas através do Conselho de Segurança em 2004, como uma medida fornecida aos governos dos países saídos dos regimes ditatoriais que pudessem adotar aqueles direcionamentos para se chegar a um regime democrático e livre.

Não existe um modelo ou regra únicos para o processo de transição e cada país deve encontrar um meio para se ligar com seu passado e implementar os mecanismos para isso. Cada país adotará o meio mais adequado a fim de conter a existência de novos distúrbios.

O modelo de transição adotado pelo Brasil na época do fim do período ditatorial foi da não punição dos responsáveis, afastando o modelo penal e punitivo dos autores dos crimes, de acordo com os preceitos da Lei de Anistia.

Dentro das regras e objetivos da Justiça de Transição, pode-se dizer que o Brasil ainda está em fase de construção, em fase de continuidade uma vez que a sociedade ainda carece de revelação de inúmeros fatos obscuros, ocultos em sua história política a partir da década de 40, sobretudo no período da Ditadura Militar, e a existência da Comissão de Verdade pode reverter esse processo.

Quanto ao requisito "verdade", integrante da Justiça de Transição, cabe também tecer algumas considerações. Discutindo asa abordagem de Michel de Foucault sobre a verdade, Teitel (2000, p. 69-70), assim a define:

[...] a história é professora e juíza, e a verdade histórica ee em si justiça. É essa visão do potencial liberalizante da história que inspira um argumento popular contemporâneo para a responsabilização histórica nas transições. Ainda, a pressuposição de que "verdade" e "história" são uma mesma coisa evidencia a crença na possibilidade de uma história autônoma e objetiva do passado desmentindo o significado do contexto político presente na formação da investigação histórica. Porém a teorização moderna sobre o conhecimento histórico desafia consideravelmente tal concepção. Quando a 
Artigo original

Hegemonia - Revista Eletrônica de Relações Internacionais do Centro Universitário Unieuro

ISSN: $1809-1261$

UNIEURO, Brasília, número 15, 2015, pp. 42-92.

história teve sua "virada interpretativa", deixou-se de ter uma singular, clara e determinada compreensão sobre uma "lição" a se tirar do passado, em vez disso passou a reconhecer um grau de dependência entre a compreensão histórica e as contingências políticas e sociais. (TEITEL. 2000, p. 69-70).

A busca da verdade, no caso brasileiro, diz respeito à prestação de informações sobre os fatos ocorridos durante o regime militar. Trata-se de um efetivo direito de vítimas, familiares e sociedade em geral ter a notícia clara e segura dos fatos ocorridos, em especial quanto aos inúmeros abusos decorrentes desse período. Esse direito à verdade é irrenunciável e inalienável, e é reconhecido internacionalmente. ${ }^{3}$

A verdade, encaixada no contexto de Justiça de Transição, consiste também em investigar, de forma transparente e independente, as sucessivas violações a direitos humanos ocorridas durante o regime ditatorial, bem como promover a identificação dos responsáveis.

Nesse sentido, mostra-se como direito das vítimas, bem como de seus familiares, o conhecimento claro sobre a verdade do que e como aconteceram os abusos referentes às torturas,

A verdade está reconhecida internacionalmente como sendo dever do Estado promover a verdade e, como consequências, preservar a memória das vítimas de violações a direitos humanos. Nesse sentido, diversos documentos consagraram o direito à verdade no âmbito internacional: ORGANIZAÇÃO DOS ESTADOS AMERICANOS. Resolução AG/RES. 2175 (XXXVI-0/06), aprovada na quarta sessão plenária, de 06 de junho de 2006. Disponível em: <>. Acesso em 2 de julho de 2013; OFICINA DEL ALTO COMISIONADO DE LAS NACIONES UNIDAS PARA LOS DERECHOS HUMANOS. Promoción y protección de los Derechos Humanos: estudos sobre el derecho a la verdad. Disponível em: <>. Acesso em 2 de julho de 2013. 
Artigo original

Hegemonia - Revista Eletrônica de Relações Internacionais do Centro Universitário Unieuro

ISSN: $1809-1261$

UNIEURO, Brasília, número 15, 2015, pp. 42-92.

desaparecimentos forçados e assassinatos nos porões do regime militar.

Para Leal (2012, p. 45) existem dois deveres para garantir o reconhecimento do direito à verdade: "o dever de lembrar e o dever de outorgar as garantias para a realização do direito de saber, do direito de informação".

Outro objetivo premente da busca da verdade é o de não deixar com que o histórico de abusos e violações se perca pelas brumas inescapáveis do esquecimento. Dessa forma, abrindo-se mão da verdade, os casos de tortura, desaparecimentos forçados e mesmo os assassinatos mais cruéis praticados durante o período de opressão, corre-se o risco de que caiam no esquecimento, tornando possível que voltem a ocorrer no futuro.

Nesse mister, as comissões da verdade desempenham papel fundamental, visto que agem como órgãos extrajudiciais de investigação, instituídos pelo Estado, com o fim de promover a reconciliação nacional. Esse é o objetivo da Comissão Nacional da Verdade, criada pela Lei no $12.528 / 2011$, no Brasil.

RESPONSABILIZAÇÃO E RECONCILIAÇÃO: A OPÇÃO PELA SANÇÃO OU PELO PERDÃO

Não há como desassociar a responsabilização daqueles que praticaram crimes hediondos e graves violações aos direitos humanos no passado recente dos países latino americanos que passaram pelos regimes ditatoriais instalados a partir da década de 1960 e que perdurou até meados da década de 1980 do atingimento do que se propõe a ser uma reconciliação nacional.

Pinto (2012, p. 61) indica que para um governo egresso de um regime autoritário e em fase de transição para o democrático, a forma a ser utilizada para estabelecer o direito e decidir o que fazer 
Artigo original

Hegemonia - Revista Eletrônica de Relações Internacionais do Centro Universitário Unieuro

ISSN: $1809-1261$

UNIEURO, Brasília, número 15, 2015, pp. 42-92.

sobre os crimes cometidos no passado é a principal questão a ser decidida.

As experiências de transição da ditadura para a democracia, na América Latina, têm provocado a necessidade de atualização dos princípios fundamentais do direito internacional dos direitos humanos. Um desses princípios emergentes consiste na obrigação do Estado investigar, processar e punir os responsáveis, informando às vítimas e à sociedade os fatos e circunstâncias de tais violações.

Atualmente, não mais se discute a respeito do cabimento ou não da responsabilidade estatal frente aos crimes cometidos durante a vigência de regimes ditatoriais. No entanto, as divergências residem na forma como a reparação deva ocorrer, se voltada exclusivamente às vítimas, se limitada ao caráter pecuniário, se através de uma ampla divulgação dos fatos, ou, ainda, se direcionada à investigação, ao processamento e à punição dos responsáveis.

Com relação à responsabilidade do Estado brasileiro pelos crimes cometidos durante o regime militar, existem alguns instrumentos normativos/legais que podem representar verdadeiros obstáculos para a sua efetivação, como, v.g., a existência da Lei $6.683 / 79$, chamada Lei de Anistia.

Importante ressaltar que essa responsabilidade não exclui a responsabilidade pessoal dos agentes estatais, tanto no que se refere à sanção penal, civil e mesmo a administrativa. Há precedentes quanto a esse entendimento nos casos históricos do Tribunal de Nuremberg e nos julgamentos dos responsáveis pelo campo de concentração de Auschwitz, que apuraram os crimes ocorridos naquele campo de segregação nazista. No entanto, essa modalidade de responsabilização é afetada, mais uma vez, pelo instituto da anistia, assim entendida por Zaneir e Teixeira, 2010, p. 488) como sendo a "exclusão, por motivo de utilidade pública, de um ou mais fatos criminosos do campo de incidência do Direito Penal pelo Poder Público, mediante lei ordinária com efeitos retroativos." 
Artigo original

Hegemonia - Revista Eletrônica de Relações Internacionais do Centro Universitário Unieuro

ISSN: $1809-1261$

UNIEURO, Brasília, número 15, 2015, pp. 42-92.

Muitas, são, aliás, as controvérsias a respeito da aplicabilidade, ou não, da Lei de Anistia Brasileira, fato que merecerá capítulo a parte na presente dissertação, o que não impede de, desde logo, adiantar as considerações sobre o tema, tecidas por Zaneir e Teixeira, 2010, p. 489), para quem a Lei de Anistia brasileira "caracteriza-se como autoanistiadora e, portanto, inválida perante a Corte Interamericana de Direitos Humanos.

Os crimes lesa-humanidade são os considerados violações dos direitos à vida, à integridade física e à liberdade, cometidos de maneira massiva e sistemática. A obrigação do Estado consiste na reparação integral (retorno ao status quo ante), assim entendida a observãncia das obrigações interdependentes entre si e inerentes à completa Justiça de Transição, quais sejam, 1) a memória; 2) a verdade; 3) a justiça e 4) reparação.

Pinto (2012, p.58), assim argumenta sobre o papel do judiciário quanto às obrigações de justiça e reparação:

O judiciário, como baluarte da defesa dos direitos humanos, deve estar preparado não para impor o respeito aos direitos humanos, mas para criar meios de introjetar esses direitos no cotidiano das pessoas, por meio da participação da comunidade e dos envolvidos na apuração, no debate e na responsabilização dos atos criminosos cometidos. Procedimentos excessivamente técnicos e formais podem isolar a sociedade do processo de reconstrução moral e reconciliação social necessário ao estabelecimento da democracia. (PINTO, 2012, p. 58).

Seguindo essa linha de entendimento, deve-se no Brasil, inequivocamente ultrapassar o esquecimento e a impunidade em nome do fortalecimento do Estado brasileiro com a proteção dos direitos humanos. A atual política de limitar a reparação ao caráter pecuniário, além de não atender ao princípio da reparação integral, relega à sociedade o dever de reparação, haja vista que as 
Artigo original

Hegemonia - Revista Eletrônica de Relações Internacionais do Centro Universitário Unieuro

ISSN: $1809-1261$

UNIEURO, Brasília, número 15, 2015, pp. 42-92.

indenizações são pagas com dinheiro público. Portanto, torna-se necessário a definição de uma nova teoria de responsabilidade estatal que leve em consideração os princípios de direito internacional supramencionados, bem como as peculiaridades dos danos decorrentes dos crimes lesa-humanidade.

Alçada como principal objetivo a ser alcançado pela Comissão Nacional da Verdade, a reconciliação mostra-se ainda um ponto distante, tanto pelas vicissitudes inerentes ao processo lento e inacabado da Justiça de Transição no Brasil, quanto os enorme óbice criado pela manutenção da constitucionalidade da Lei de Anistia, a partir do julgamento da ADPF 153.

COLETA DE DEPOIMENTOS E METODOLOGIA UTILIZADA NA ANÁLISE DO DISCURSO ACERCA DA JUSTIÇA DE TRANSIÇÃO NO BRASIL

Os termos métodos e técnicas de pesquisa são, geralmente, utilizados como sinônimos. Entretanto, são bastante distintos entre si. Cano (2012, p.94) deixa clara essa diferença: Métodos seriam estratégias de produção de conhecimento científico, incluindo a geração e a validação de teorias. Técnicas seriam formas padronizadas de coleta e análise de dados, com a mesma finalidade, a de produzir conhecimento válido.

Existem, pois, técnicas capazes de fazer quantificações e também registros não quantificados. Para Cano (2012, p. 107) a quantificação é um aspecto muito visível, porém, secundário do ponto de vista epistemológico. Para o pesquisador, contudo, é necessário avaliar minuciosamente tanto as evidências quantitativas quanto as qualitativas para se obter conclusões válidas.

Preambularmente à análise dos depoimentos arrecadados, mostra-se imperioso delimitar a noção do discurso como ferramenta linguística e ideológica, visando a leitura analítica do discurso político que se apresenta nas entrevistas que seguem a esta pesquisa. 
Artigo original

Hegemonia - Revista Eletrônica de Relações Internacionais do Centro Universitário Unieuro

ISSN: $1809-1261$

UNIEURO, Brasília, número 15, 2015, pp. 42-92.

Para Pinto (2006, p. 79) há muitas incorreções quanto ao efetivo conceito de discurso:

O conceito de discurso é muitas vezes equivocadamente usado como sinônimo de pronunciamento, de texto formal. Não há nenhum problema em se usar a palavra 'discurso' para nomear pronunciamentos, entretanto, quando se trata de Teoria do Discurso, isto leva a um erro grave. Em uma sociedade como a nossa, uma grande parte dos discursos se expressa na escrita, mas também há importantes discursos visuais, desde as manifestações artísticas até a própria moda. Nada mais cheio de significado, nada mais discursivo do que a forma de vestir dos adolescentes, por exemplo. (PINTO. 2006, p. 79).

Essas considerações tem o objetivo de, segundo Pinto (2006, p. 79) de não confundir o discurso com pronunciamentos, ainda que estes sejam efetivamente formas também de discurso. Ainda, segundo a autora, a análise de discurso não é uma forma de análise de conteúdo: são estas perspectivas completamente distintas. A análise de conteúdo mostra-se como um método de análise de texto; análise de discurso é uma teoria dos sentidos, das significações. Pontifica a pesquisadora que as técnicas da análise de conteúdo pouco ou nada ajudam na análise do discurso.

Nesse contexto, Pinto (2006, p. 80) menciona a existência do discurso como uma tentativa de dar sentido ao real, e de fixar sentidos. Esta tentativa mostra-se precária mas exitosa: precária no sentido de não ser essencial e por isso, constantemente ameaçada de ser desconstruída; exitosa porque, no que pese a ameaça, contém uma continuidade histórica.

As interpretações de Pinto sugerem ênfase no desenvolvimento de dois pontos essenciais abordados por ela. O primeiro, o fato de que a afirmação da não essencialidade do discurso não tem nada a ver com a ideia de falso ou de manipulação. Não se pode olvidar de 
Artigo original

Hegemonia - Revista Eletrônica de Relações Internacionais do Centro Universitário Unieuro

ISSN: $1809-1261$

UNIEURO, Brasília, número 15, 2015, pp. 42-92.

que há discursos falsos e manipulados, entretanto é tema para a análise a partir de hipóteses de trabalho. De acordo com Pinto (2006, p. 81) o que é importante para o bom andamento da explicação da teoria é ter claro que a falsidade ou a manipulação não advém da natureza não essencial dos sentidos. Já o segundo ponto abarca a noção de que os discursos, assim interpretado "na medida em que contém significados incorporados por sujeitos, que os constroem ou são por eles subjetificados, provocam efeitos concretos, na forma das pessoas se relacionarem entre si, nas formas como a história toma os seus rumos."

O sentido da provisoriedade fica bem claro nas lições de Pinto (2006, p. 81):

não se trata de uma condição de constante mudança, mas que sinaliza que se não lutarmos todos os dias para que os nossos direitos continuem sendo direitos, nós podemos perdê-los. Porque aquela cláusula pétrea que diz que todos nós temos o direito à vida foi um acordo construído discursivamente. Ou seja, se não lutarmos por isto, nós podemos perder este direito. Porque este é apenas um discurso provisório, com êxito, mas arbitrário.

A pesquisadora aponta alguns exemplos que ilustram sua interpretação do discurso, entre eles o fato de um terremoto acontecido em uma região qualquer, quando não havia população nesta região: nós não podemos pensar nele porque ninguém deu sentido a ele, portanto ele não existe para ninguém. A condição pode mudar se estudiosos de alguma ciência ligada à terra, fizerem uma análise geológica e chegarem à conclusão que há um milhão de anos houve um terremoto lá. Desta forma está sendo atribuído sentido a este terremoto e ele passa a ter efeitos em outros discursos. 
Artigo original

Hegemonia - Revista Eletrônica de Relações Internacionais do Centro Universitário Unieuro

ISSN: $1809-1261$

UNIEURO, Brasília, número 15, 2015, pp. 42-92.

Segue Pinto (2006, p. 82) exemplificando de modo ilustrativo, mencionando que, em sequência ao exemplo dado acima, outro terremoto acontece na mesma região durante a existência de uma civilização, que vive o terremoto como conseqüência da ira dos deuses, porque a forma como eles estavam se comportando não era a correta e que devido a isso teriam de fazer alguns sacrifícios humanos, matar um grupo de virgens e entregá-las aos deuses, para que os terremotos não mais acontecessem. A nossa percepção como seres humanos do século XXI é: nós sabemos a verdade sobre os terremotos. Eles não sabiam. Daí que podemos pensar que o que está ocorrendo é um enfrentamento entre a verdade atual e engano anterior. Sabemos que o terremoto é uma manifestação da acomodação das camadas geológicas da Terra, cientificamente se chegou a esta conclusão. Tomam-se certas medidas para diminuir os seus efeitos: constroem-se casas seguras, ruas largas, treinam-se as populações para se salvarem. Entretanto, isto não é tão simples assim: nós estamos plenamente convencidos, no século XXI, de que chegamos a todas as verdades por conta da ciência. Contudo, a pergunta que permanece é se daqui a mil anos não estarão dizendo os cientistas que era um absurdo o que, ao redor do ano dois mil, se pensava sobre terremotos? Por que nós temos tanta certeza que nosso discurso chegou à verdade?

Em conclusão silogística aos exemplos apontados, conclui Pinto (2006, p. 82):

O que é importante enfatizar é a força desse rompimento com a noção de uma verdade anterior a qualquer significação. Porque, quando nós observamos os discursos das civilizações que nos antecederam, e que tinham relações místicas com as forças da natureza, ficamos surpresos e dizemos: "que horror, mataram pessoas em função das forças da natureza", sendo que nossa civilização mata por razões bem menos ameaçadoras. Os exemplos como o das forças da natureza são sempre mais fáceis de serem construídos e entendidos, porém se faz necessário aqui pensar no discurso a partir de questões éticas e comportamentais. Pensemos no seguinte 
Artigo original

Hegemonia - Revista Eletrônica de Relações Internacionais do Centro Universitário Unieuro

ISSN: $1809-1261$

UNIEURO, Brasília, número 15, 2015, pp. 42-92.

cena: em uma rua, em uma das grandes cidades do Brasil um policial bate em um menino negro. Qual o sentido desta cena? O que é verdade sobre esta cena?. Se a testemunha da cena for uma pessoa de muita idade, que já foi assaltada cinco vezes e que está apavorada com a violência, dirá: "até que enfim, um policial batendo num marginal que está atrapalhando a vida da cidade, ainda bem que apareceu um policial para acabar com isto". Se a testemunha for um indivíduo racista fará um discurso ainda mais marcado contra o menino negro. Mas se a testemunha for um representante de uma ONG de direitos humanos, possivelmente dirá: "esta é uma cena de violência de um policial em relação a uma criança". Nos três discursos a cena é a mesma. Assim como no terremoto, que tem diferentes discursos sobre ele, uma cena simples na rua, também. Tomando uma questão social como exemplo: como o MST é construído no Brasil? É impossível chegar a uma verdade sobre o MST. Ele é significado tanto como um movimento social, como um movimento totalitário que vai tomar o poder e acabar com a democracia. Isto porque ele está inserido em discursos diferentes. O que cabe ao analista de discurso é "desconstruir", analisar como este MST é construído em cada um destes discursos. Isso não é uma tarefa literária. Isso é uma tarefa para compreender os espaços onde atores, partidos, movimentos atuam, agem e modificam a vida contemporânea. (PINTO, 2006, p.82).

$\mathrm{Na}$ análise que segue quanto aos depoimentos colhidos em relação à visão concebida por cada sujeito abordado sobre a Justiça de Transição no Brasil procuramos nos abster de considerar como verdades esses discursos, buscando, sim, analisar cada um deles situado em um espaço-tempo-cultura própria do sujeito.

Dessa forma, ao eleger determinados cidadãos cujo posicionamento muitas vezes notórios quanto ao tema ensejam de antemão suas interpretações quanto à completa ou incompleta Justiça de Transição no Brasil, não tencionou o pesquisador apenas ratificar essas posições quando do colhimento dos depoimentos analisados, mas, antes, analisar comos esses discursos foram construídos e de que forma são replicados por esses agentes. 
Artigo original

Hegemonia - Revista Eletrônica de Relações Internacionais do Centro Universitário Unieuro

ISSN: $1809-1261$

UNIEURO, Brasília, número 15, 2015, pp. 42-92.

Brandão (2013, p. 32) vaticina importantes conceitos apresentados por Foucault necessários para uma pesquisa e análise do discurso:

Foucault (1969) concebe os discursos como uma dispersão, isto é, como sendo formados por elementos que não estão ligados por nenhum princípio de unidade. Cabe à análise do discurso descrever essa dispersão, buscando o estabelecimento de regras capazes de reger a formação dos discursos. Tais regras, chamadas por Foucaul de "regras de formação", possibilitariam a determinação dos elementos que compõem o discurso, a saber: os objetos que aparecem coexistem e se transformam num "espaço comum" discursivo; os diferentes tipos de enunciação que podem permear 0 discurso; os conceitos em suas formas de aprecimento e transformação em um campo discursivo, relacionados em um sistema comum; os temas e teorias, isto é, o sistema de relações entre diversas estratégias capazes de dar conta de uma formação discursiva, permitindo ou excluindo certos temas ou teorias.

O verdadeiro desafio a ser encarado na análise do discurso é, segundo Brandão (2013, p. 103), o de realizar leituras críticas e buscar a reflexão de modo a não reduzir o discurso a análises superficiais de aspectos puramente linguísticos nem o dissolvam num trabalho eminentemente histórico sobre a ideologia nele predominante. Nesse mister, a presente pesquisa buscou evitar 0 caminho fácil da interpretação gramatical dos depoimentos colhidos, buscando, antes, confrontá-los com o cenário temporal, o espaço e o posicionamento ideológico em que foram proferidos. 
Artigo original

Hegemonia - Revista Eletrônica de Relações Internacionais do Centro Universitário Unieuro

ISSN: $1809-1261$

UNIEURO, Brasília, número 15, 2015, pp. 42-92.

CONTEXTO ESPACIAL E TEMPORAL DA REALIZAÇÃO DAS ENTREVISTAS

Por ocasião dos 50 anos do Golpe Militar ocorrido a partir de 31 de março de 1964, o Senado e a Câmara dos Deputados organizaram sessões solenes, respectivamente nos dias 31 de março e $1^{\circ}$ de abril de 2014, para lembrar a efeméride. Participamos, como ouvintes, dessas sessões no intuito de arrecadar material a robustecer a presente dissertação, os quais são colacionados a seguir.

A sessão no Senado foi proposta pelo Senador João Capiberibe (PSB-AP) ${ }^{4}$, ele mesmo uma vítima da mão pesada da ditadura, quando em meados da década de 1960 foi preso e torturado, vindo a se exilar por longo período, tendo voltado ao Brasil somente em 1979, com a anistia.

Na sessão, alguns senadores defenderam, em seus discursos, a revisão da Lei de Anistia para que os militares responsáveis por crimes como tortura, morte e desaparecimento sejam levados à julgamento. A Senadora Ana Rita (PT-ES) abriu os discursos bradando a imperiosa necessidade de punições: "É preciso rever a Lei de Anistia e a exemplo de países vizinhos, como a Argentina, punir o autoritarismo do Estado e atos como torturas, desaparecimentos e mortes" - disse a senadora, que citou projetos nesse sentido de autoria da deputada Luiza Erundina (PSB-SP) ${ }^{5}$ e do senador Randolfe

Disponível em . Acesso em 18.4.2014.

PL-573/2011 - Dá interpretação autêntica ao disposto no art. 10, § 10, da Lei no 6.683, de 28 de agosto de 1979. Disponível em. Acesso em 17.4.2014. 
Artigo original

Hegemonia - Revista Eletrônica de Relações Internacionais do Centro Universitário Unieuro

ISSN: $1809-1261$

UNIEURO, Brasília, número 15, 2015, pp. 42-92.

Rodrigues (PSOL-AP) ${ }^{6}$. A senadora preside a Comissão de Direitos Humanos do Senado.

Em seguida, o Senador Randolfe Rodrigues afirmou da tribuna que "É preciso reconhecimento dos autores de tudo que ocorreu. A Lei de Anistia só serviu a um lado, dos torturadores. A anistia foi só para eles. A revisão é necessária." (10.4.2014).

João Capiberibe também foi na mesma linha, asseverando que "conforme a sociedade vai tomando conhecimento do que ocorreu naquele período, cresce nessa mesma sociedade o desejo de revisão da Lei de Anistia." (10.4.2014).

Em 10 de abril, na sessão da Câmara dos Deputados, a Deputada Luiza Erundina proferiu longo discurso em memória daqueles que foram perseguidos, torturados e mortos pelo regime militar. Logo após a sua participação foi anunciado o próximo orador, Deputado Jair Bolsonaro, representante da vertente militar no Congresso.

No ano de 2000, Jair Bolsonaro defendeu, numa entrevista à revista IstoÉ ${ }^{7}$, a utilização da tortura em casos de tráfico de droga e sequestro e a execução sumária em casos de crime premeditado. Segundo ele, "O objetivo é fazer o cara abrir a boca. O cara tem que ser arrebentado para abrir o bico." Bolsonaro foi criticado pelos meios

PL-237/2013 - Dá nova definição ao "crime conexo" estabelecido na Lei da Anistia de 1979. Em linhas gerais, o texto abre caminho para sanções contra agentes públicos, militares e civis que atentaram contra aqueles que se opunham ao regime de governo vigente no período abrangido pela Lei da Anistia, classificando essas ações como crime político e desassociando-as do crime conexo. Disponível em http://www.ocafezinho.com/2014/04/07/senado-examina-revisaoda-lei-da-anistia/\#sthash.ho8cBUGp.dpuf. Acesso em 17.4.2014.

. Istoé Gente. Edição impressa de 9 de abril de 2011. 
Artigo original

Hegemonia - Revista Eletrônica de Relações Internacionais do Centro Universitário Unieuro

ISSN: $1809-1261$

UNIEURO, Brasília, número 15, 2015, pp. 42-92.

de comunicação, por políticos e pelo Grupo Tortura Nunca Mais, sobretudo depois de ter afixado na porta de seu escritório um cartaz que dizia aos familiares dos desaparecidos da ditadura militar "quem procura osso é cachorro." ${ }^{\prime 8}$

Na sessão da Câmara de $1^{0}$ de abril, assim que o Deputado Jair Bolsonaro se alojou junto à tribuna de onde iria proferir seu discurso em defesa das Forças Armadas e sua atuação durante os anos de governo dos militares, os deputados, senadores e cidadãos que assistiam à sessão, em sua flagrante maioria, deram às costas ao orador, o que provocou no Deputado Amir Lando, que presidia a sessão, um inflamado e veemente arroubo de repreensão ao ato, prometendo suspender a sessão caso os presentes não se voltasse para ouvir Bolsonaro. Como a plateia permaneceu de costas, em protesto, Amir Lando suspendeu a sessão durante cinco minutos, dos quais os presentes entoaram com vigor o Hino Nacional Brasileiro. Passados os cinco minutos e retomada a sessão, o seu presidente novamente advertiu que o Regimento Interno da Câmara dos Deputados proibia aquele tipo de manifestação e caso não cessasse, a sessão solene seria encerrada. Malgrado a intervenção de parlamentares que defendiam a manifestação, invocando o direito à livre expressão garantido pela Constituição Brasileira, o Deputado Amir Lando encerrou a sessão, sem que o Deputado Jair Bolsonaro fizesse sua oratória adrede preparada.

Nessa oportunidade, após a tumultuada sessão solene, foram colhidos, no salão verde do Congresso Nacional, os depoimentos que seguem, ouvidos o Senador Randolfe Rodrigues (PSOL-AP); o Deputado Federal Chico Alencar (PSOL-RJ); o Deputado Federal Jean Willys (PSOL-RJ); o Deputado Federal Amir Lando (PMDB-RO) e o Deputado Federal Jair Bolsonaro (PP-RJ).

Acesso em 14.4.2014. 
Artigo original

Hegemonia - Revista Eletrônica de Relações Internacionais do Centro Universitário Unieuro

ISSN: $1809-1261$

UNIEURO, Brasília, número 15, 2015, pp. 42-92.

No dia 24 de abril do mesmo ano, foi colhido, por mensagem eletrônica, as ponderações da Doutora Rosa Cardoso, membro da Comissão Nacional da Verdade.

A todos foi apresentada a seguinte indagação; "qual é a sua avaliação acerca da política de Justiça de Transição adotada no Brasil?".

\section{COLETA DE DADOS DAS FONTES PRIMÁRIAS E SECUNDÁRIAS}

Impende ressaltar, inicialmente, que a construção da indagação, nos termos como foi apresentada, procurou agregar à pergunta conteúdo que esteja vinculado ao problema desenvolvido ao longo da pesquisa, bem como à hipótese nela apresentada desde o preâmbulo deste artigo.

Dessa forma, ao se apresentar aos depoente a indagação "qual é a sua avaliação acerca da política de Justiça de Transição adotada no Brasil?", tem-se como objeto esperado resposta que auxilie na apreciação do problema levantado de que a criação da Comissão Nacional da Verdade, limitada quanto à atuação em investigar e relatar sobre os crimes praticados durante o período militar no Brasil e o alcance de sua finalidade de promover a reconciliação nacional, sem que haja a indicação de indiciamentos para que os investigados sejam julgados pelos seus delitos pode ou não configura-se como instrumento apto a promover a reconciliação nacional.

Assim, a partir da técnica qualitativa escolhida para subsidiar, em parte, as conclusões deste trabalho científico, buscou-se interpretar a partir de agentes envolvidos diretamente no tema Justiça de Transição, se a CNV atingirá seu objetivo de promover a reconciliação nacional, ainda que não haja punições, alcançando, 
Artigo original

Hegemonia - Revista Eletrônica de Relações Internacionais do Centro Universitário Unieuro

ISSN: $1809-1261$

UNIEURO, Brasília, número 15, 2015, pp. 42-92.

dessa maneira, a hipótese cuja gênese é aludida no sentido de que a ausência de um dos requisitos da tríade componente da Justiça de Transição a tornaria uma política incompleta, nesse caso por conta não da memória e verdade, mas da justiça (responsabilização).

À técnica qualitativa, entretanto, junta-se a técnica quantitativa, promovida a partir de fontes secundárias, em especial às pesquisas colacionadas junto ao instituto DataFolha e ao Instituto de Pesquisa Econômica Aplicada - IPEA, cuja análise dos dados também são objeto deste artigo.

A construção da pergunta também direciona para eventuais respostas esperadas, cuja consolidação promove o desenvolvimento do problema e da hipótese já mencionadas, que são objeto da pesquisa. É dizer, sendo a resposta da fonte primária detratora quanto à política de Justiça de Transição adotada no Brasil, uma vez que não promove a responsabilização dos agentes violadores dos direitos humanos, em confronto com a maioria dos Estados sulamericanos que optaram por promover essa responsabilização, direciona para a análise de que, a juízo dessas fontes, a hipótese de que não haverá êxito na missão da CNV em alcançar o objetivo de reconciliação nos termos dispostos na lei que a criou é a mais evidente.

De outra sorte, caso extraído da análise desses depoimentos que a Justiça de Transição adotada no Brasil cumpre os anseios da sociedade, mesmo sem a responsabilização dos torturadores a serviço do regime militar, estar-se-á angariando importante informação que leva a responder ao problema inicial de forma que a hipótese não se configurará, ou seja, a CNV poderá alcançar seu objetivo, promovendo a reconciliação sem responsabilização.

Necessário repisar que optou-se por uma complementação ao método (técnica) de pesquisa qualitativa, somando as observações nela extraídas aos dados adquiridos a partir das pesquisas quantitativas, carreadas ao trabalho científico por meio de fontes secundárias retratadas como sendo de lavra do DataFolha e do IPEA. 
Artigo original

Hegemonia - Revista Eletrônica de Relações Internacionais do Centro Universitário Unieuro

ISSN: $1809-1261$

UNIEURO, Brasília, número 15, 2015, pp. 42-92.

Dado o cenário exposto inicialmente, adentra-se ao contexto inerente à coleta dos depoimentos de fontes primárias, objetos da análise qualitativa dos dados angariados.

O primeiro entrevistado foi o Senador da República, Raldolfe Rodrigues, eleito pelo Partido Socialismo e Liberdade - PSOL, representante do estado do Amapá. A escolha do seu nome como fonte primária de pesquisa ampara-se no fato de ser dele o Projeto de Lei no 237, de 2013, que pretende a revisão da Lei 6.683/1979 (Lei da Anistia), de forma que esta não proteja aqueles que, em nome do regime militar, cometeram graves violações contra os direitos humanos, assim entendidos os desaparecimentos forçados, torturas e mortes dos opositores ao regime vigente de 1964 a 1985. Randolfe também foi autor, juntamente com o Senador Pedro Simon, do Partido da Mobilização Democrática Brasileira - PMDB, do Rio Grande do Sul, da proposta de anulação da sessão do próprio Congresso do dia 2 de abril de 1964, que decretou vaga a Presidência da República e depôs o ex-presidente João Goulart, o Jango, em ato que deu início ao regime militar brasileiro.

A abordagem se deu logo após o encerramento da curta sessão solene em memória dos que lutaram contra o Golpe Militar instalado no Brasil em alusão aos 50 anos da derrubada do governo de João Goulart. O Senador, assim como vários outros políticos que estavam na sessão se alojaram no chamado "Salão Verde", área que interliga o acesso à Câmara dos Deputados e ao Senado Federal. Randolfe Rodrigues acabara de discursar para algumas pessoas que ali se encontravam, falando do horror que sucedeu ao Golpe Militar, bem como da omissão do Estado brasileiro quanto à punição dos torturadores. Assim que acabou seu discurso foi abordado por alguns jornalistas que lhe questionaram sobre o que acabara de acontecer na tumultuada sessão solene da Câmara. Após atender aos jornalistas, o Senador Randolfe Rodrigues, assim respondeu à seguinte indagação apresentada "qual é a sua avaliação acerca da política de Justiça de Transição no Brasil?": 
Artigo original

Hegemonia - Revista Eletrônica de Relações Internacionais do Centro Universitário Unieuro

ISSN: $1809-1261$

UNIEURO, Brasília, número 15, 2015, pp. 42-92.

(a Justiça de Transição) É uma necessidade imperiosa. A atual Lei de Anistia foi parida e surgida no meio da ditadura. Foi uma imposição do regime autoritário. Foi aprovada pelo partido da ditadura por seis votos de diferença. Ela não serviu para trazer os presos políticos de volta, tanto é que a ampla maioria, ela não serviu pra trazer os exilados de volta, tanto é que a maioria dos presos políticos só tiveram a libertação política, única e exclusivamente, pela expiração de suas penas. Elas só cumpriam um objetivo: impedir que aqueles que torturam e mataram durante a ditadura não respondessem pelos crimes que cometeram. Em todas as ditaduras, em especial do continente Latino-americano, houve a responsabilização daqueles que cometeram crimes durante os regimes autoritários, aqui no Brasil é que não. É fundamental rever essa lei. Não é possível completar a democracia no Brasil sem a revisão da lei da Anistia. A gente não completa o processo de transição democrática se a lei da anistia não for revista no Brasil.

Na mesma data, 10.4.2014, e no mesmo contexto, após a sessão solene sobre os 50 anos do Golpe Militar, encerrada minutos antes na Câmara dos Deputados, o pesquisador abordou o Deputado Federal Jean Wyllys, filiado também ao Partido Socialismo e Liberdade - Psol do Rio de Janeiro. O entrevistado surgiu como fonte primária por conta do trabalho desenvolvido na Frente Parlamentar em Defesa dos Direitos Humanos, onde desempenha o papel de coordenador, sendo reconhecido através de vários prêmios ${ }^{9}$ pelo

Em 2011, Jean Wyllys foi homenageado com o Prêmio Trip Transformadores, foi o segundo mais votado nas categorias "Melhor deputado" e "Parlamentar de futuro" em seu ano de estréia no Prêmio Congresso em Foco, foi eleito, pela revista Época, um dos 100 brasileiros mais influentes em 2011 e pela pela revista Isto É, como uma das 100 personalidades mais influentes para 2012. Disponível no site. Acesso em 3.5.2014. 
Artigo original

Hegemonia - Revista Eletrônica de Relações Internacionais do Centro Universitário Unieuro

ISSN: $1809-1261$

UNIEURO, Brasília, número 15, 2015, pp. 42-92.

engajamento na temática de direitos humanos. Também é atuante no parlamento quanto ao tema Justiça de Transição no Brasil, tendo apoiado firmemente e ajudado a colher assinaturas ao projeto de Lei no 237/2013, de autoria do Senador Randolfe Rodrigues, correligionário de seu partido, o Psol.

A abordagem ao Deputado Federal Jean Wyllys deu-se no Salão Verde do Congresso Nacional, momentos após o encerramento da sessão solene dos 50 anos do Golpe Militar, realizada na Câmara dos Deputados. O entrevistado estava ouvindo os discursos que se seguiam no sentido de repudiar a tentativa de pronunciamento do Deputado Jair Bolsonaro na sessão solene, fato este que encerrou a sessão, dado o tumulto que se seguiu ao anúncio da fala de Jair Bolsonaro. Ao Deputado Federal Jean Wyllys também foi apresentada a seguinte pergunta: "qual é a sua avaliação acerca da política de Justiça de Transição no Brasil?". A resposta foi, na sua integralidade, a que segue:

Olha, não há justiça em transição, essa é a verdade né. O Governo Federal montou uma comissão que é tão somente da verdade, mesmo assim talvez da meia verdade. A verdade historiográfica e as verdades da ditadura talvez não venham à tona graças à essa comissão. A comissão deveria ser comissão de justiça, quer dizer, deveria haver a temporada de julgamento dos torturadores, dos criminosos, não vai haver. Então eu vejo que não há muita justiça em transição. É necessário rever (a Lei da Anistia) porque criminosos não podem ficar impunes, porque pessoas foram torturadas, porque houve voos da morte, porque há pessoas desaparecidas, porque há famílias lamentando até hoje por seus mortos. Por isso não pode, a lei da Anistia tem que ser revista. Não pode se anistiar criminosos né. Anistiar as vítimas, os censurados, os exilados, tudo bem, os acusados de crimes políticos. Mas os torturadores, os criminosos não. Então a lei tem que ser revista. 
Hegemonia - Revista Eletrônica de Relações Internacionais do Centro Universitário Unieuro

ISSN: $1809-1261$

UNIEURO, Brasília, número 15, 2015, pp. 42-92.

Ainda em 10.4.2014, o pesquisador colheu o depoimento do Deputado Chico Alencar, filiado ao Partido Socialismo e Liberdade PSOL, do Rio de Janeiro. Chico Alencar foi membro titular da Comissão de Direitos Humanos e Minorias - CDHM, no período de 10.3.2011 a 31.1.2012. É também de sua autoria o Projeto de Lei no $1.124 / 2011$, que propõe que os crimes cometidos por agentes públicos, militares ou civis, contra pessoas que, de modo efetivo ou suposto, praticaram atos contra a segurança nacional e a ordem política e social, não sejam incluídos entre os crimes conexos definidos pela Lei da Anistia. Os efeitos desta lei serão consideradas em vigor desde a data de promulgação da lei da Lei da Anistia, caso aprovada.

Conforme supramencionado, após o encerramento prematuro da sessão solene dos 50 anos do Golpe Militar, os participantes rumaram para o Salão Verde que dá acesso ao Senado Federal. Foi lá que o pesquisador abordou o Deputado Chico Alencar, que acabara de dar uma entrevista ao canal TV Justiça e a ele foi apresentada a seguinte pergunta: "qual é a sua avaliação acerca da política de Justiça de Transição no Brasil?". A resposta foi, na sua integralidade, a que segue:

No Brasil é notório "transições intransitivas", a nossa história é marcada por isso. Eu dou exemplos notórios: A independência foi feita por um príncipe português, que aliás ao abdicar do trono em 1831 foi assumir o trono em Portugal, não sei se você sabe mas Dom Pedro IV, nosso Dom Pedro I é considero herói nacional em Portugal. Negócio de pai para filho e que manteve latifúndio, monocultura e escravidão, país que nasceu em 1822 tinha essas continuidades do período colonial. A república foi proclamada por um general monarquista, Deodoro era inclusive amigo pessoal de Dom Pedro II. A revolução de 30 não foi revolução coisa nenhuma, foi uma recomposição do bloco de poder com segmentos urbanos e da burguesia industrial que estava nascendo, mas o presidente da província de Minas, Antônio Carlos, foi muito elucidativo, o que ele disse à época? "Façamos a revolução antes que o povo à faça". O Estado novo de Vargas foi o Estado do velho conceito nazi-fascismo. A nossa 
Artigo original

Hegemonia - Revista Eletrônica de Relações Internacionais do Centro Universitário Unieuro

ISSN: $1809-1261$

UNIEURO, Brasília, número 15, 2015, pp. 42-92.

democratização em 45 foi limitada tanto que em dois anos depois o partido comunista foi colocado na ilegalidade. A revolução de 64, dita revolução, foi feita pra salvar a democracia no Brasil, e os militares ficariam muito pouco tempo no poder, até a eleições presidenciais marcadas pra 65, ficaram 21 anos. Então a transição mesmo para a democracia, apesar da luta de tantos e tantos que perderam vida, foi uma transição pactuada com os governantes militares, por isso eles impuseram, num congresso castrado com senadores biônicos, um modelo de Anistia que só passou mesmo a ser por cinco votos. Então a nossa justiça de transição é na verdade uma justiça de imobilismo, de conciliação pelo alto, de acerto entre os setores dominantes. A gente tem que avançar nisso, ai depende do movimento social, da luta popular, e de mais consciências batalhando por essa verdadeira democratização do Brasil, que ainda está em curso.

O Deputado Federal Amir Lando também foi relacionado pelo Pesquisador como fonte primária do trabalho científico, principalmente em razão de sua notória posição considerada mais conciliadora sobre o tema Justiça de Transição. Amir Francisco Lando é deputado federal pelo Partido do Movimento Democrático Brasileiro - PMDB, representando o estado de Rondônia. Na ocasião em que o depoimento foi colhido, qual seja, em 10 de abril de 2014, logo após a sessão solene realizada pro ocasião dos 50 anos do Golpe Militar, o Deputado Amir Lando era o presidente da sessão solene, a tendo encerrado por conta do tumulto já narrado no início deste capítulo.

Dessa forma, o entrevistado foi abordado no Salão Verde do Congresso Nacional, a ele sendo apresentada a seguinte pergunta: "qual é a sua avaliação acerca da política de Justiça de Transição no Brasil?". A resposta segue conforme degravação fidedigna de sua resposta:

Bem, eu tenho uma visão que a Anistia é um perdão de ambas as partes, não é de uma parte para outra. Não é uma concessão do vencedor contra o vencido, e nem vice-versa, a 
Artigo original

Hegemonia - Revista Eletrônica de Relações Internacionais do Centro Universitário Unieuro

ISSN: $1809-1261$

UNIEURO, Brasília, número 15, 2015, pp. 42-92.

Anistia se estabelece como uma tentativa de conciliação nacional. Evidentemente a política sempre teve dois lados ou mais, a política é um conflito, a política na democracia é, sobretudo, contraditório e a garantia desse contraditório. Então, uma vez encerrado esse capítulo, essa democracia que nós lutamos, que eu também lutei, foi exatamente pra reconquistar esse direito do devido processo legal; esse direito do contraditório do processo legal; esse direito das liberdades democráticas, e até eu busco mais as liberdades concretas. Então eu vejo que nós temos que encerrar esse capítulo, esse capítulo não pode ser ressuscitado, seria sim, claro, saber a verdade é uma coisa, mas não mais com o intuito de revê-la e estabelecer punições novas pra quem quer que seja.

O último depoimento colhido na data de 10.4.2014, foi junto ao Deputado Federal Jair Bolsonaro, filiado ao Partido Popular - PP, representando o estado do Rio de Janeiro na legislatura 2011-2015.10 O parlamentar é membro da Comissão de Direitos Humanos e Minorias, da Câmara dos Deputados e externa posicionamento francamente contrário aos trabalhos da Comissão Nacional da Verdade - CNV ${ }^{11}$ além de ser um representante do seguimento militar no parlamento, bem como entusiasta do Golpe Militar ocorrido em $1964 .^{12}$

Disponível em . Acesso em 6.5.2014.

"Tanto eles têm medo da verdade, que criaram uma comissão dizendo ser da verdade, para a qual Dilma Rousseff indicou sete integrantes, cinco dos quais advogados. Ora, advogados têm compromisso com o cliente, não com a verdade. $E$ massacram as Forças Armadas diuturnamente. Sr. Presidente, eu peço a V.Exa., eu quase imploro a V.Exa., que me dê 15 minutos para contar a história do que houve antes do 31 de março de 1964 até 1985, e de 1985 para cá." Discurso proferido na Câmara dos Deputados em 25.3.2014 disponível em . Acesso em 6.5.2014.

"Sr. Presidente, Sras. e Srs. Deputados, o Exército nunca foi intruso na política. Ele sempre foi instrumento da vontade popular. Sessenta e quatro foi uma exigência da sociedade. As mulheres nas ruas pediam o restabelecimento da ordem. Os empresários não queriam ver seu patrimônio estatizado pelo golpe de esquerda que se avizinhava. A mídia clamava pelos militares. Toda a Igreja Católica pedia a Deus para que os militares assumissem. A OAB e a ABI eram as mais exaltadas em prol dos militares. Em 2 de abril de 1964, o Congresso Nacional, e não os militares, cassou o mandato de João Goulart. Em 9 de abril de 1964, este mesmo Congresso elegeu Castelo Branco para presidir o Brasil, 
Hegemonia - Revista Eletrônica de Relações Internacionais do Centro Universitário Unieuro

ISSN: $1809-1261$

UNIEURO, Brasília, número 15, 2015, pp. 42-92.

Em 10 de abril, após a sessão solene realizada sobre o tema 50 anos do Golpe Militar, o Deputado Jair Bolsonaro permaneceu ainda por cerca de 30 minutos no plenário, atendendo a imprensa que cobria o acontecimento. Após esse lapso de tempo, dirigiu-se ao Salão Verde do Congresso Nacional, onde se amontoavam jornalistas, deputados que haviam participado da sessão e também cidadãos que tinham assistido ao evento. Foi nesse local que se colheu $o$ depoimento do Deputado a partir da seguinte pergunta: "qual é a sua avaliação acerca da política de Justiça de Transição no Brasil?". A resposta segue abaixo, conforme degravação fidedigna de sua resposta:

Olha, a comissão da verdade foi totalmente loteada por Dilma Rousseff. Todos os seus sete integrantes foram colocados por ela lá. Não existe nenhum historiador, e todos tem uma passagem pela luta armada, todos sem exceção. Assim sendo ela não tem isenção. Ela não tem isenção tá. Você pode ver, é a mesma coisa que um grupo de sete traficantes fosse escolhidos pra compor o tribunal do júri e julgar o Fernandinho Beira-Mar, tá na cara que ele seria absolvido, eles têm tanto a lei da verdade que eles blindaram a comissão da verdade, inclusive muitos depoimentos são isenções secretas. Como esse coronel agora, que é conhecido na sua região como o homem que se identifica com 0 Saddam Hussein, o primeiro depoimento quando ele falou que cortava dedos, etc., fazia aquela desgraça toda né?! Ele é... foi uma bomba na imprensa. No dia seguinte ele já começou a não falar coisa com coisa, e na terceira passou então pra isenção secreta, onde eles começaram a filtrar o que ele fala, e o que ele fala, de acordo com o interesse da comissão, passou a ser a verdade.

inclusive com o voto de Ulysses Guimarães. Foram 20 anos de pleno emprego, segurança e respeito aos humanos direitos. Passamos da $49^{a}$ para $8^{a}$ economia do mundo, mesmo com duas crises do petróleo. Só no Governo Médici foram construídas 15 hidrelétricas. Com Geisel e Figueiredo, veio Itaipu Binacional e também Usina de Angra. Sem as obras dos militares o Brasil não existiria. Os Ministros eram escolhido 
Artigo original

Hegemonia - Revista Eletrônica de Relações Internacionais do Centro Universitário Unieuro

ISSN: $1809-1261$

UNIEURO, Brasília, número 15, 2015, pp. 42-92.

(sobre o Regime Militar) Olha eu poderia falar em vários aspectos tá. O Brasil não seria o que é sem as obras realizadas pelos militares. Se você pegar só na questão da energia que tá no momento, uma crise que se aproxima aí, só Médici fez quinze hidrelétricas né. Depois Geisel e Figueiredo fizeram, entre outras, Itaipu binacional e a nuclear de Angra. Nos onze anos de PT eles não fizeram nada. E não é só nessa área, não fizeram nada em lugar nenhum. A única obra do PT é o porto lá em Mariel, que tá servindo né, com toda a certeza, como os recursos são secretos, pra uma parte da grana voltar pra cá. Bem, no tocante à democracia foi excepcional, porque o partido comunista desde antes de meia quatro né, aliado de Fidel Castro, Mao Tse Tung, etc., eles queriam impor, fazer valer a sua ideologia. E foram pra luta armada e tentaram de toda maneira conseguir impor sua ideologia. Perderam a guerra. Inclusive perderam em cheio lá no Araguaia, por que se nós aqui tivéssemos permitido que eles lá crescessem, no mínimo hoje nós teríamos uma Farc no coração do Brasil.

Buscando informações de fontes primárias que pudessem contribuir de forma robusta quanto aos esclarecimento acerca dos trabalhos desenvolvidos pela Comissão Nacional da Verdade e, ainda, sobre a efetividade de seus trabalhos mesmo não havendo possibilidade de o relatório final subsidiar indiciamentos e punições aos agentes do Estado eventualmente identificados pela CNV, o pesquisador tentou por diversas vezes colher o depoimento dos membros da Comissão Nacional da Verdade.

No dia 24.4.2014, o pesquisador recebeu a mensagem eletrônica da ouvidoria da Comissão Nacional da Verdade - CNV, encaminhando o que afirmou ser a resposta da Dra. Rosa Cardoso à questão "qual é a sua avaliação acerca da política de Justiça de Transição adotada no Brasil?". A transcrição que segue abaixo é literal ao texto encaminhado na referida mensagem eletrônica, creditada à Dra Rosa Cardoso, membro da CNV. 
Artigo original

Hegemonia - Revista Eletrônica de Relações Internacionais do Centro Universitário Unieuro

ISSN: $1809-1261$

UNIEURO, Brasília, número 15, 2015, pp. 42-92.

A autoanistia imposta pelos militares que se encontravam no poder em 1979 é um empecilho para a completa Justiça de Transição no Brasil. Essa autoanistia, esse termo, advém do fato de que foi concedida ainda em um período de autoritarismo no Brasil, quando os governantes militares é que determinavam o desenvolvimento do processo de abertura, que ainda não existia naquele momento. O fato é que com a Lei da Anistia não há possibilidade de julgamento, e em termos do que se considera a efetiva passagem de um regime autoritário para um democrático, é necessário, sim, que haja julgamento. De que forma cada país conduz esse julgamento, ou seja, que sanções deve impor, como por exemplo prisão domiciliar ou outra forma. Tenho repetido que para um regime autoritário passar a ser um regime efetivamente democrático, é preciso que haja a judicialização dessas questões. É preciso deixar claro que não se trata de revanchismo, apenas a compreensão mais próxima do que convencionou chamar de direito internacional dos direitos humanos, ampliando a Justiça de Transição para atender o direito à verdade, memória e justiça.

Por fim, no dia 3.6.2014, nova mensagem eletrônica encaminhada pela Ouvidoria da Comissão Nacional da Verdade encaminhava resposta genérica à pergunta "'qual é a sua avaliação acerca da política de Justiça de Transição adotada no Brasil?".

A Comunidade e a Doutrina Internacional mencionam quatro obrigações do Estado: a) adotar medidas razoáveis para prevenir violações de direitos humanos; b) oferecer mecanismos e instrumentos que permitam a elucidação de situações de violência; c) dispor de um aparato legal que possibilite a responsabilização dos agentes que tenham praticado as violações; e d) garantir a reparação das vítimas, por meio de ações que visem a reparação material e simbólica. O Brasil tem garantido a reparação das vítimas por meio da Comissão da Anistia, instalada em 28 de agosto de 2001. A Comissão Nacional da Verdade, bem como a Comissão Especial de Mortos e Desaparecidos Políticos vêm elucidando os fatos relacionados às graves violações de direitos humanos. Ao final dos trabalhos, a Comissão 
Artigo original

Hegemonia - Revista Eletrônica de Relações Internacionais do Centro Universitário Unieuro

ISSN: $1809-1261$

UNIEURO, Brasília, número 15, 2015, pp. 42-92.

Nacional da Verdade irá apresentar o relatório
circunstanciado contendo as atividades realizadas, os fatos
examinados, as conclusões e recomendações. Tais
recomendações visam a adoção de medidas e políticas
públicas para prevenir violações de direitos humanos,
assegurar a sua não repetição e promover a efetiva
reconciliação nacional. Atenciosamente, Ouvidoria -
CNV

Percebe-se a utilização de um tom mais pragmático na derradeira resposta encaminhada pela Ouvidoria da CNV, talvez resultado de determinação interna, causada pelas eventuais rusgas entre os próprios membros da Comissão Nacional da Verdade, divididos entre aqueles que são favoráveis a que o relatório final de seus trabalhos contenha sugestão de responsabilização dos agentes do Estado que praticaram graves violações aos direitos humanos e aqueles que pretendem tão somente identificar os responsáveis e esclarecer a verdade dos fatos até então restrito aos arquivos militares brasileiros, sem indicação de responsabilização judicial.

ANÁLISE E INTERPRETAÇÃO DE DADOS COLHIDOS ACERCA DA JUSTIÇA DE TRANSIÇÃO NO BRASIL

A partir das considerações lançadas pelos entrevistados, segue a análise dos dados colhidos.

Percebe-se, mesmo a partir de um reduzido quadro de entrevistados, porém de significativa importância per si, que as 
Artigo original

Hegemonia - Revista Eletrônica de Relações Internacionais do Centro Universitário Unieuro

ISSN: $1809-1261$

UNIEURO, Brasília, número 15, 2015, pp. 42-92.

divergências sobre a Justiça de Transição efetivada até o presente no Brasil, pululam de formas incisivas entre aqueles que entendem não haver de forma plena e de modo a alcançar a reconciliação do país com sua memória, verdade e justiça e aqueles que entendem que a transição do período autoritário para o democrático completou-se de forma pacífica e não há se falar em responsabilização dos agentes que agiram em nome do Estado para cometer crimes durante o regime militar, uma vez que a anistia tem que falar para ambos os lados, a favor ou contra a ditadura.

A análise do Senador Randolfe Rodrigues remonta ao fato de que a Lei de Anistia é fato histórico preponderante para evitar a completa Justiça de Transição no Brasil. Nesse ponto converge aos dizeres da Doutora Rosa Cardoso, que também rememora ter sido a Lei de Anistia uma autoanistia, promovida pelos próprios interessados, no caso, os militares que ainda detinham o poder quando da sua aprovação por mínimos 6 votos de diferença. O Senador ressalta, ainda, o fato de que a norma anistiadora só serviu aos propósitos dos algozes da ditadura, uma vez que "ela não serviu pra trazer os exilados de volta, tanto é que a maioria dos presos políticos só tiveram a libertação política, única e exclusivamente, pela expiração de suas penas." Nesse ponto, reitera que apenas serviu para "impedir que aqueles que torturam e mataram durante a ditadura não respondessem pelos crimes que cometeram."

Já a manifestação do Deputado Federal Jean Wyllys mostra-se contundente quanto à inexistência de uma política de Justiça de Transição no Brasil, por não haver seus requisitos formadores verdade, memória e justiça - mas tão somente ser uma comissão da verdade, ainda assim, ressalva, "uma meia verdade", tendo em vista que segundo a sua interpretação "a verdade historiográfica e as verdades da ditadura talvez não venham à tona graças à essa comissão." Nesse ponto, alia-se o Deputado ao conceito trazido a balha nesta dissertação por Piovesan (2012, p. 212), para quem não resta dúvidas de que os pressupostos da Justiça de Transição - direito à memória, à verdade e à justiça (esta vista como o direito de 
Artigo original

Hegemonia - Revista Eletrônica de Relações Internacionais do Centro Universitário Unieuro

ISSN: $1809-1261$

UNIEURO, Brasília, número 15, 2015, pp. 42-92.

reparação e reformas institucionais) - estão entrelaçadas, sendo a concretização de um pressuposto dependente do avanço do outro. Por essa glosa, convergem o entendimento de ambos quanto à inexistência da efetiva Justiça Transicional à falta de um de seus requisitos. A afirmativa, então, do Deputado no sentido de que "não há Justiça de Transição" assemelha-se ao entendimento de Elster (2004, p. 1), no sentido de que Justiça de Transição se define como "um processo de julgamentos, depurações e reparações que se realizam após a mudança de um regime para outro." No caso brasileiro, o cenário é justamente o oposto, ou seja, não houve um único julgamento até hoje daqueles que ensejaram o desrespeito aos direitos humanos mínimos durante o regime militar, daí a contundência de entrevistado, Deputado Federal Jean Wyllys.

O depoimento do Deputado Federal Chico Alencar acrescenta aos já analisados uma ponderação sobre a história de "transições intransitivas" explicada por ele a partir dos paradoxos apresentados em momentos decisivos da história nacional, ilustrando que desde a formação do Estado Brasileiro, em 1822 até a redemocratização ocorrida a partir de 1985 o país deixou inacabados os processos de transição do Estado Português para o Estado Brasileiro, do oligopólio presente na política do Café-com-Leite à Revolução de 30 e desta para a o fim do Estado Novo e, ainda, do Golpe de 1964 para a democracia que, segundo ele, ainda está em curso. Interessante conclusão se abstrai dos dizeres do Deputado, qual seja, o Golpe de 1964 nasceu como uma Revolução, uma vez que a "revolução de 64, dita revolução, foi feita pra salvar a democracia no Brasil, e os militares ficariam muito pouco tempo no poder, até a eleições presidenciais marcadas pra 1965, ficaram 21 anos", silogismo que leva à entender que, caso o militares mantivessem o ajuste inicial de que permaneceriam no poder tão somente até o próximo pleito presidencial agendado para 1965, a retirada por eles do governo legítimo de João Goulart se justificaria à bem da democracia. Ainda, a conclusão do Deputado sobre a Justiça de Transição no Brasil é semelhante à dos entrevistados que o antecederam nesta análise, 
Artigo original

Hegemonia - Revista Eletrônica de Relações Internacionais do Centro Universitário Unieuro

ISSN: $1809-1261$

UNIEURO, Brasília, número 15, 2015, pp. 42-92.

visto que se mostra uma transição pautada na "conciliação pelo alto" feita nos domínios dos dominantes à época, os próprios militares e civis que apoiaram o golpe.

Abrindo um posicionamento divergente, o Deputado Amir Lando, que presidiu a sessão solene em memória dos 50 anos do Golpe Militar, ocorrida em 10 de abril de 2014, manifestou-se no sentido de que não deve haver a responsabilização dos agentes que cometeram violações aos direitos humanos naquele período, uma vez que, segundo ele, a anistia deve ser para ambas as partes, vencedores e vencidos. Nesse sentido, entende o entrevistado que a conciliação é possível ainda que a Justiça de Transição não esteja preenchida de todos os seus requisitos, no caso, a justiça (responsabilização). Essa interpretação colide com a do Senador Randolfe Rodrigues e a dos Deputados Jean Willys e Chico Alencar, mas encontra simpatia daqueles que entendem que o modelo de Justiça de Transição no Brasil tem aspectos semelhantes ao adotado na África do Sul, onde não houve julgamento dos que representavam a classe dominante branca que oprimiu e impingiu aos negros práticas nefastas como as adotadas aqui para reprimir os descontentes. Há, porém, que se ressaltar que o modelo africano foi mais do que um simples esquecimento das atrocidades cometidas durante o apartheid, sendo alcançado após inúmeras audiências da Comissão da Verdade e Reconciliação em que foram colhidos depoimentos dos acusados pelos crimes de racismo e, após, a confissão e retratação por parte destes, caracterizando uma típica justiça restaurativa. No Brasil, é importante repisar que nunca houve por parte dos representantes das Forças Armadas, nem mesmo do Clube Militar, retratação ou mesmo admissão da prática de torturas e assassinatos e muito menos um pedido formal de desculpas por essas práticas.

Adotando discurso condizente com sua formação militar, o Deputado Federal Jair Bolsonaro preferiu atacar frontalmente a própria Comissão Nacional da Verdade e o critério escolhido para sua formação, afirmando categoricamente que ela foi "loteada" pela Presidente da República, Dilma Rousseff, suscitando que haja 
Artigo original

Hegemonia - Revista Eletrônica de Relações Internacionais do Centro Universitário Unieuro

ISSN: $1809-1261$

UNIEURO, Brasília, número 15, 2015, pp. 42-92.

interesse meramente político nos trabalhos da Comissão. Robustece essa tese o fato de que, segundo o Deputado, não compõe o grupo nenhum historiador e sim pessoas ligadas à luta armada e, por isso mesmo, não possuem a isenção necessária para apresentar um relatório hígido. O entrevistado chega a, de forma jocosa, comparar os membros da Comissão a traficantes que julgam o seu maior líder, no caso, Fernandinho Beira Mar, atestando que ao final o veredicto seria certeiro naquele caso, como será provavelmente desabonadora a conclusão da CNV quanto às práticas dos militares durante os anos de 1964 a 1985. Aliás, depreende-se do depoimento do Deputado que não houve irregularidades por parte daqueles que comandaram o país durante o regime militar, pelo contrário, atesta o depoente que se não fosse pela intervenção ocorrida em 1964, o Brasil estaria ainda mais cambaleante em diversos setores da economia, em especial, na questão da energia elétrica, concluindo que a governança dos generais salvou o Brasil de ter em seu espaço territorial o problema enfrentado pela Colômbia em relação às Farc (Forças Armadas Revolucionárias da Colômbia).

Concluindo o universo das entrevistas, a Doutora Rosa Cardoso reafirma seu entendimento de que no Brasil não houve simplesmente uma anistia amparada por um ordenamento legal, e sim uma autoanistia, configurada no cenário estabelecido para sua própria promulgação, qual seja, em pleno regime militar, os generais utilizaram-se da sua força política configurada por uma (ainda) maioria no parlamento que possibilitou a aprovação de um normativo que isentava os próprios autores de graves crimes cometidos até aquele momento de qualquer responsabilização pelos seus atos, transmutando-se a Lei em verdadeiro salvo-conduto para as verdadeiras barbaridades que em nome do regime foram levadas a cabo. A militante história em direitos humanos observa que a Lei da Anistia é impeditivo de que julgamentos venham a ocorrer no Brasil a despeito até mesmo de um eventual veemente relatório da CNV que aponte os nomes dos agentes que cometeram crimes naquele lapso de tempo. Sendo assim, uma vez que para ela a transição entre 
Artigo original

Hegemonia - Revista Eletrônica de Relações Internacionais do Centro Universitário Unieuro

ISSN: $1809-1261$

UNIEURO, Brasília, número 15, 2015, pp. 42-92.

regimes autoritários para regimes democráticos deve passar pelo triunvirato inerente à Justiça de Transição, qual seja, memória, verdade e justiça, no Brasil, pendente este último, a transição nunca estará completa. A advogada criminalista, que atuou em defesa de presos políticos no Rio de Janeiro, em São Paulo e no Distrito Federal, preocupou-se em deixar claro que seu posicionamento não se assemelha a revanchismo, mas da própria completude do conceito de Justiça de Transição, amparada pelo contexto internacional de direitos humanos.

O método qualitativo empreendido nessas entrevistas permite, de um lado depreender antagonismos evidentes entre aqueles que defendem uma Justiça de Transição completa no Brasil, qualificada como sendo aquela que compreende além de políticas que incentivem a memória e a verdade dos acontecimentos do período militar também a responsabilização daqueles que contribuíram para 0 cometimento de crimes contra os direitos humanos, neles enquadrados o Senador Randolfe Rodrigues, os deputados Jean Wyllys e Chico Alencar, bem como a advogada e militante de direitos humanos, Rosa Cardoso e de outro lado o Deputado Jair Bolsonaro, que nega veementemente os ilícitos computados aos militares e é francamente contra a Comissão Nacional da Verdade por não merecer da sua parte legitimidade para apurar os fatos, uma vez que não a possui isenção necessária. Recortada desse cenário maniqueísta, resta a opinião do Deputado Amir Lando, que embora não desmereça os trabalhos de tentativa de reconciliação do país com o seus passado ainda vivo, entende que não deve haver punições, e que o melhor é seguir em frente sem "ressuscitar" o passado.

Os dados colhidos nesse pequeno universo reiteram o relatório de pesquisa apresentado pelo instituto DataFolha ${ }^{13}$, com relação a pesquisa realizada em março de 2014, onde, entre outros dados, foi apontado o expressivo número de cidadãos que são a favor da 


\section{Artigo original}

Hegemonia - Revista Eletrônica de Relações Internacionais do Centro Universitário Unieuro

ISSN: $1809-1261$

UNIEURO, Brasília, número 15, 2015, pp. 42-92.

revisão da Lei de Anistia, carreando, entretanto, dado surpreendente quanto ao número desses cidadãos que são favoráveis não só à punição dos agentes do Estado que cometeram esses crimes, mas também daqueles que lutaram contra o regime militar e praticaram crimes com semelhantes. A pesquisa mostra, ainda, que o tema é de conhecimento restrito a uma pequena parcela da população com maior nível de escolaridade.

De acordo com a pesquisa do instituto Datafolha divulgada na edição de 31 de março de 2014 do jornal Folha de São Paulo, 46\% dos brasileiros são favoráveis à anulação da norma da Lei da Anistia da forma que ela é aplicada atualmente. Outros $37 \%$ são contra e $17 \%$ não souberam dizer sua opinião. 
Artigo original

Hegemonia - Revista Eletrônica de Relações Internacionais do Centro Universitário Unieuro

ISSN: $1809-1261$

UNIEURO, Brasília, número 15, 2015, pp. 42-92.

JUSTIÇA DE TRANSIÇÃO

Resposta estimulada é única, em \%

VOCÊ É A FAVOR OU CONTRA A ANULAÇÃO

DA LEI DA ANISTIA?

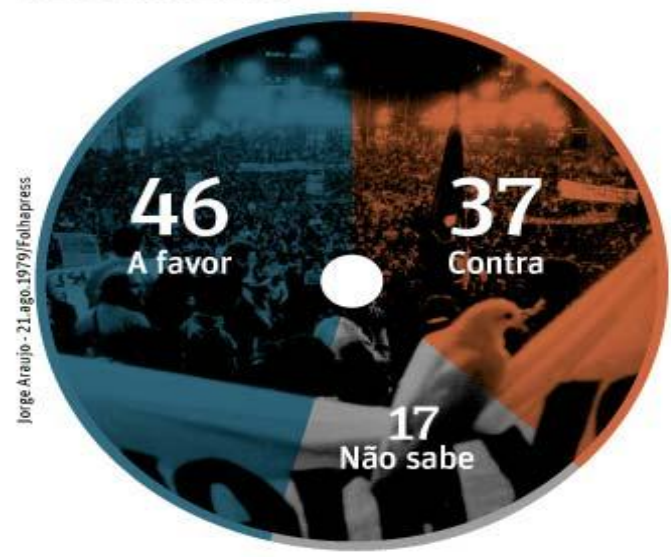

Você é a favor ou contra a punição de pessoas que torturaram presos políticos durante a ditadura?

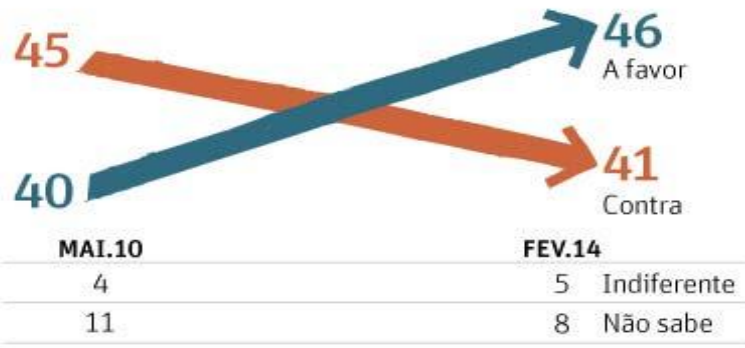

\begin{abstract}
Polícia e Judiciário devem reexaminar os casos de atentados contra o governo durante a ditadura?
\end{abstract}

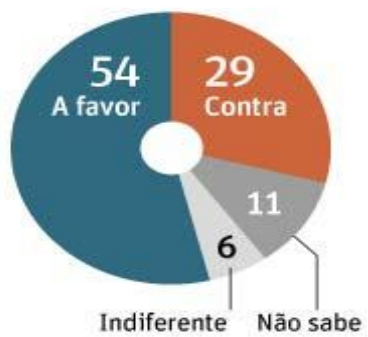

São acusados de tortura, assassinato e sequestro tanto ex-membros do governo quanto ex-militantes de esquerda. Quem deveria ser julgado hoje?

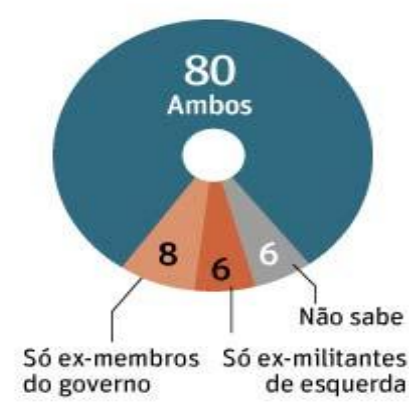

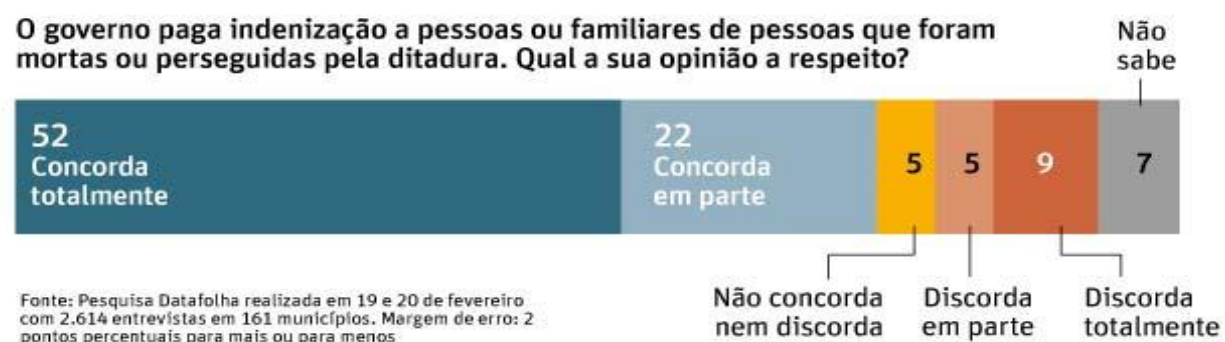

Outro dado interessante dessa pesquisa é a constatação de que $46 \%$ defendem castigo aos torturadores e $41 \%$ são contra. Indiferentes e pessoas que não souberam opinar são 13\%. Em 2010, 
Artigo original

Hegemonia - Revista Eletrônica de Relações Internacionais do Centro Universitário Unieuro

ISSN: $1809-1261$

UNIEURO, Brasília, número 15, 2015, pp. 42-92.

quando o Datafolha fez essa pergunta pela primeira vez ${ }^{14}$, o resultado foi o inverso: $45 \%$ eram contra, $40 \%$ a favor. A pesquisa atual, com 2.614 entrevistas, foi feita em 19 e 20 de fevereiro de 2014.

O Instituto de Pesquisa Econômica Aplicada - IPEA, por sua vez, já havia divulgado em 29 de janeiro de 2012 a pesquisa Sistema de Indicadores de Percepção Social (SIPS), que trata da defesa nacional. Em sua terceira edição, ela revelou que boa parte dos brasileiros desconhece a Lei de Anistia. Mas, entre os que têm conhecimento, a maioria manifestou ser favorável à investigação sobre os crimes cometidos durante a ditadura e algum tipo de punição para os responsáveis.

O SIPS Defesa Nacional ouviu 3.796 pessoas, em todas as unidades da federação. As duas primeiras edições da pesquisa abordaram, respectivamente, a percepção de ameaças (dezembro de 2011) e percepções sobre a Defesa Nacional e as Forças Armadas, o poder militar do Brasil e sua inserção internacional (janeiro de 2012).

O tema referente à Lei da Anistia foi abordado no sentido de haver uma discussão no país sobre a possibilidade ou necessidade dessa lei ser revista para que possa haver a investigação e/ou a punição de crimes cometidos durante o regime militar no Brasil. A grande maioria dos entrevistados, $74,8 \%$, afirmou simplesmente desconhecer ou apenas ter ouvido falar do tema, sem saber do que se tratava. Essa porcentagem foi de $80,3 \%$ entre os entrevistados não escolarizados ou com ensino fundamental (incompleto ou completo), de $74,8 \%$ entre os de nível médio (incompleto ou completo) e de $52,6 \%$ entre os de nível superior (incompleto ou completo) ou pós-graduação. O grau de desconhecimento está mais presente na Região Nordeste: $57,7 \%$ dos entrevistados afirmaram que sequer haviam ouvido falar da Lei da Anistia. Essa foi a resposta de $33,4 \%$ dos entrevistados do Sudeste e de 40,2\% dos entrevistados da Região Sul. 
Artigo original

Hegemonia - Revista Eletrônica de Relações Internacionais do Centro Universitário Unieuro

ISSN: $1809-1261$

UNIEURO, Brasília, número 15, 2015, pp. 42-92.

FIGURA B - PESQUISA IPEA - SIPS - 2012

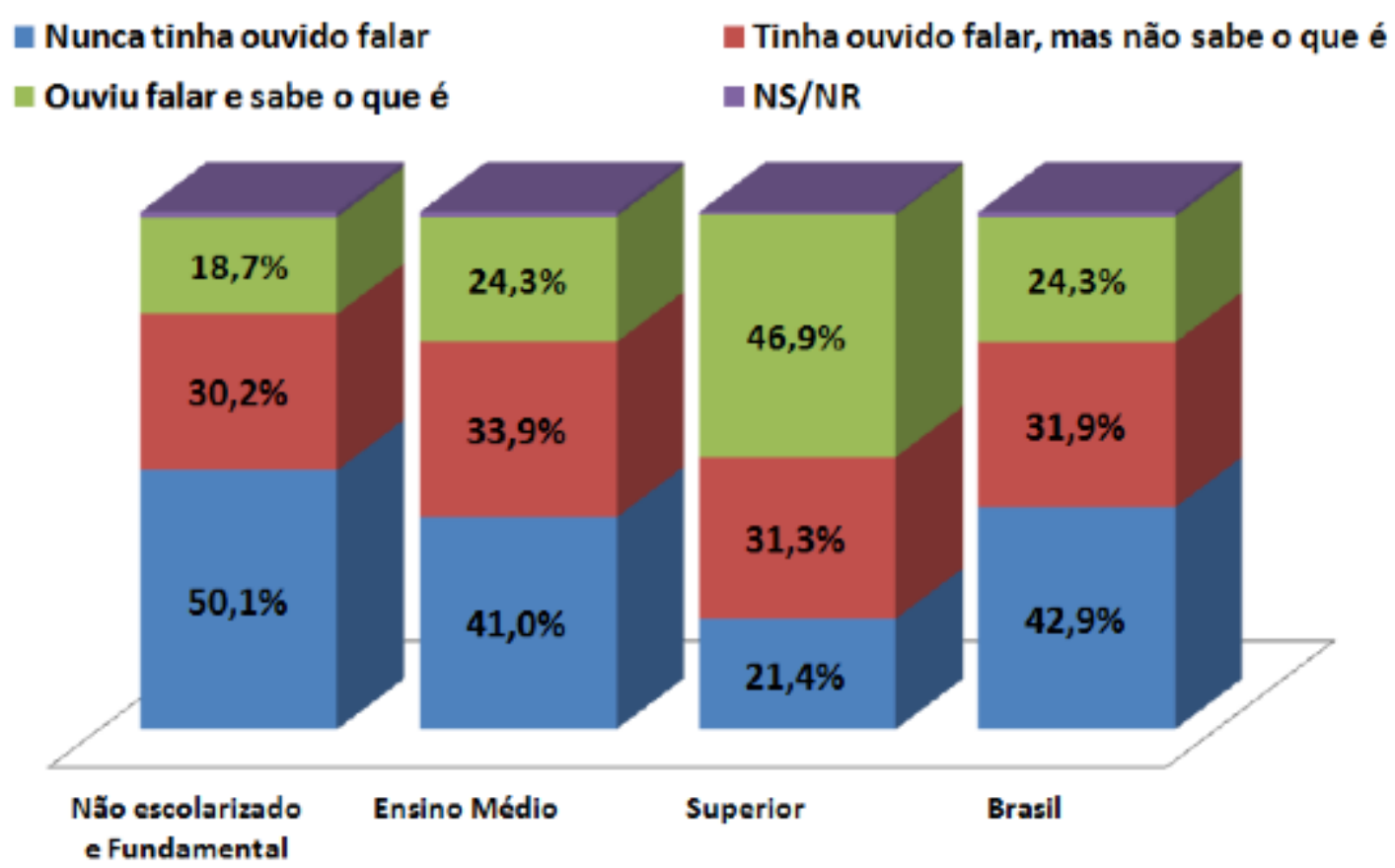

Fonte IPEA. SIPS. FEV.2012. 
Artigo original

Hegemonia - Revista Eletrônica de Relações Internacionais do Centro Universitário Unieuro

ISSN: $1809-1261$

UNIEURO, Brasília, número 15, 2015, pp. 42-92.

FIGURA C - PESQUISA IPEA - SIPS - 2012

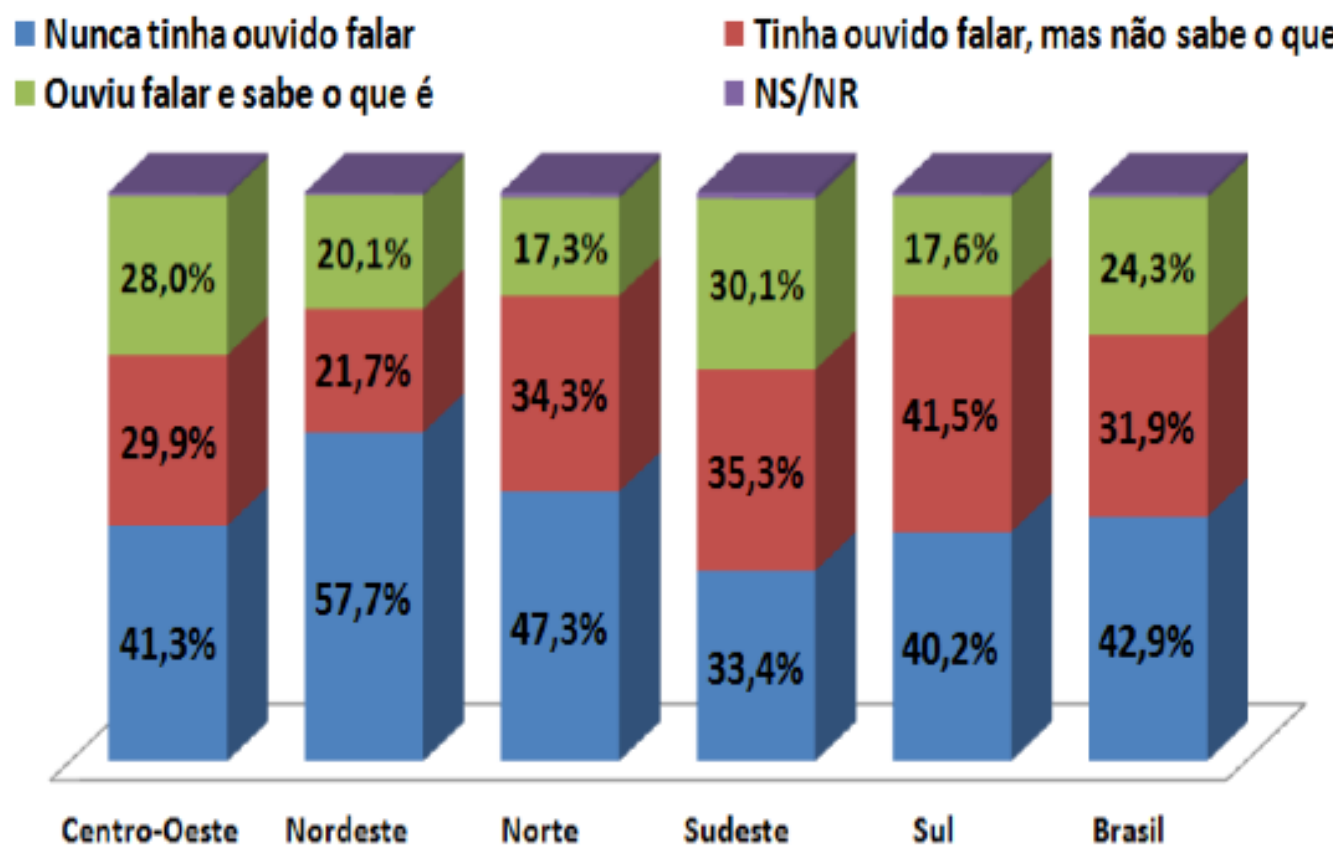

Fonte IPEA. SIPS. FEV.2012.

Aos entrevistados que responderam saber do que se tratava a Lei da Anistia (24,3\% do total) foi perguntado se deveria haver ou não algum tipo de investigação e/ou punição para crimes cometidos durante o regime militar.

Ainda segundo a pesquisa realizada pelo IPEA, para 20,3\% dos entrevistados que conhecem o tema não deveria haver nenhum tipo de investigação. Para $11,8 \%$ deveria haver investigação dos crimes cometidos durante o regime militar, mas sem punições, enquanto para os $67 \%$ restantes deveria haver investigacăo e algum tipo de punição (sendo 22,2\% apenas para agentes da repressão, 11,4\% apenas para integrantes de grupos armados de oposição e 33,4\% para todos os envolvidos). 
Artigo original

Hegemonia - Revista Eletrônica de Relações Internacionais do Centro Universitário Unieuro

ISSN: $1809-1261$

UNIEURO, Brasília, número 15, 2015, pp. 42-92.

\section{FIGURA D - PESQUISA IPEA - SIPS - 2012}

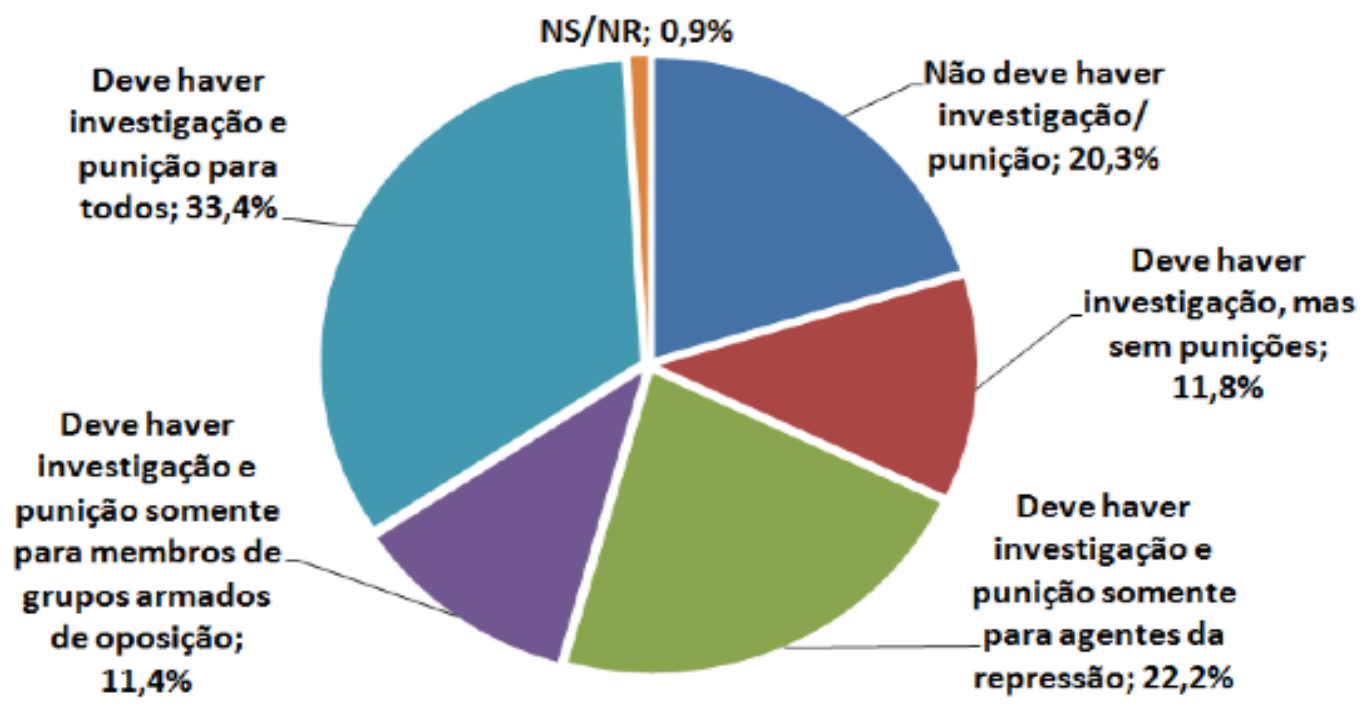

Fonte IPEA. SIPS. FEV.2012.

A lamentável conclusão que se chega a partir das entrevistas realizadas com os congressistas acima identificados, bem como da representante da CNV e, ainda, a partir dos dados extraídos das pesquisas apresentadas pelo Instituto DataFolha e pelo IPEA é a de que o tema Justiça de Transição não é pauta de reivindicação da maioria dos brasileiros, estando restrito a pequena parcela de pessoas bem instruídas e, mesmo entre estas, a responsabilização dos agentes que cometeram graves violações aos direitos humanos durante a ditadura não é questão resolvida, sendo que a maior parcela dos entrevistados que afirmaram conhecer o tema, manifestou a opinião de que os crimes cometidos durante o regime militar devem ser investigados e que deve haver algum tipo de punição tanto para os que agiam em nome do Estado quanto para os que lutaram contra a ditadura.

O alijamento da discussão sobre a anistia junto às camadas mais vultuosas da população confirma-se no fato de que esse tema não foi objeto da pauta nem mesmo dos jovens que foram às ruas 
Artigo original

Hegemonia - Revista Eletrônica de Relações Internacionais do Centro Universitário Unieuro

ISSN: $1809-1261$

UNIEURO, Brasília, número 15, 2015, pp. 42-92.

nas manifestações de junho de 2013. Questões como a contrariedade ao aumento de tarifa de transporte público, a derrubada da PEC 37 que pretendia mitigar a competência do Ministério Público para investigar crimes, gastos públicos para a realização da Copa do Mundo no Brasil, corrupção nos estertores do poder e outras demandas da ampla pauta de reivindicações não consagraram a indignação daquela massa em razão da Lei da Anistia impedir a responsabilização daqueles que cometeram graves violações de direitos humanos.

Essa alienação de considerável parcela da população acerca da Justiça de Transição no Brasil contribui proporcionalmente para que sua completude permaneça emperrada. Mesmo em 2010, quando o julgamento da ADPF 153 esteve em curso no Supremo Tribunal Federal, jogando luzes sobre o debate quanto a validade da Lei de Anistia, com ampla divulgação dos meios de comunicação, o tema não ressoou como deveria junto aos cidadãos médios, ficando restrito ao debate entre intelectuais e militantes de direitos humanos. Não estando inserta na lista de anseios da sociedade é pouco provável que os projetos em curso no Senado e na Câmara Federal tenham grandes chances de serem aprovados, permanecendo o Brasil, portanto, com um dos poucos países da América do Sul a preferir o esquecimento à uma efetiva justiça, precedida por projetos de incentivo à memória e à verdade.

\section{CONCLUSÃO}

Os regimes democráticos que sucederam às ditaduras enfrentaram o dilema de perdoar ou punir os crimes, os excessos de violência e as injustiças ocorridas durante as ditaduras. Esse é o campo da Justiça de Transição. Conforme apresentado ao longo do presente estudo, a Justiça de Transição deve ter requisitos inerentes à sua completude. 
Artigo original

Hegemonia - Revista Eletrônica de Relações Internacionais do Centro Universitário Unieuro

ISSN: $1809-1261$

UNIEURO, Brasília, número 15, 2015, pp. 42-92.

Pelo disposto, pode-se concluir que há três grandes objetivos ínscios à Justiça de Transição.

O primeiro é satisfazer as vítimas da violência e da atuação arbitrária do Estado. Para tanto, é oferecida a reparação material (indenizações, aposentadorias, reintegraçnao ao serviço público, anulação de condenações) ou moral (pedidos de desculpas por autoridades estatais, abertura de arquivos, identificação dos agentes da repressão).

Em segundo lugar, pacificar a sociedade, eliminando tensões e animosidades entre grupos políticos que continuam apoiando 0 regime anterior e as forças ligadas ao novo governo. Medidas de perdão, como a anistia, em determinadas situações e contextos de cada país, promovem a conciliação e pagam a conta com um compromisso.

Em terceiro lugar, tomar providências políticas para evitar que tal experiência se repita. Para tanto, são feitas reformas do Estado, campanhas de esclarecimento da opinião públicas e realizam-se atos simbólicas de resgate da memória (monumentos, museus, exposições, instituição de datas comemorativas).

Dependendo do país e do momento histórico, foram adotadas várias soluções. Em alguns países os responsáveis decidiram "esquecer" o passado, colocando um ponto final. Foi assim concedida uma ampla anistia, ou seja, um perdão geral aos responsáveis e aos colaboradores dos regimes ditatoriais. Esse foi o caminho seguido pelo Brasil.

Em outros países, foi decidido processar os golpistas e os responsáveis pelos males causados durante as ditaduras (Argentina, Uruguai, Paraguai, Alemanha, Grécia). Quem defendeu os colaboradores do regime apresentou argumentos tais como: o réu simplesmente aplicava o direito em vigor (argumento da legalidade); - réu acatava ordens dadas por seus superiores hierárquicos, cumprindo com seus deveres e não cabia a ele examinar a legalidade das ordens ou as intenções de seus superiores (argumento do dever 
Artigo original

Hegemonia - Revista Eletrônica de Relações Internacionais do Centro Universitário Unieuro

ISSN: $1809-1261$

UNIEURO, Brasília, número 15, 2015, pp. 42-92.

legal); se o réu tivesse colaborado com o regime, teria sido gravemente sancionado e mesmo exposto a perseguições junto a seus familiares, algo que ninguém pode exigir de uma pessoa comum (argumento da inelegibilidade de conduta diversa); se o réu não tivesse executado as ordens, os ditadores encontrariam facilmente outras pessoas que teriam atuado da mesma forma ou até com maior rigor (argumento da fungibilidade); o dano causado pelo acusado é um verdadeiro detalhe diante das incontáveis atrocidades de uma ditadura e sua punição significaria castigar um bode expiatório (argumento da insignificância).

Quem aceita tais argumentos deveria absolver praticamente todos os acusados, considerando como únicos culpados o restrito grupo dos chefes da ditadura dos quais emanavam as ordens iniciais.

A problemática foi tratada na Alemanha em uma ampla jurisprudência após o fim da Segunda Guerra Mundial, em 1945. A maioria dos tribunais descartou a tese da legalidade do regime nazista com base em dois argumentos. Em primeiro lugar, foi considerado que as normas jurídicas que contrariam o sentimento de humanidade e de justiça não possuem validade jurídica. Em segundo lugar, foi considerado que tribunais nacionais e internacionais devem julgar graves violações dos direitos humanos, principalmente, crimes de guerra e crimes contra a humanidade: genocídio; perseguição por motivos religiosos, étnicos, políticos ou de orientação sexual; guerra imperialista. Para viabilizar esses processos foi necessário criar leis penais retroativas, violando o princípio universal da legalidade. Mesmo assim, as estatísticas indicam que a maioria dos colaboradores do regime permaneceu impune, já que grande parte dos políticos e dos integrantes do poder judiciário não considerou adequada a punição, em parte porque tinham simpatias pelo regime nazista, em parte porque consideravam ser preferível pacificar o país.

No Chile e na Argentina, as políticas de reparac,ão foram acordadas pelos primeiros governos de transição e implementadas, em certa medida, com um consenso básico fora da confrontac,ão política, embora com algumas limitaç̃̃es. Nesses países, a 
Artigo original

Hegemonia - Revista Eletrônica de Relações Internacionais do Centro Universitário Unieuro

ISSN: $1809-1261$

UNIEURO, Brasília, número 15, 2015, pp. 42-92.

responsabilização judicial dos agentes do Estado que cometeram excessos foi possível, o que viabilizou a abertura de processos judiciais contra agentes, havendo, hoje, um número expressivo de pessoas processadas e condenadas por violaç̃os a direitos humanos durante a ditadura militar.

É interessante notar que tanto o Congresso Nacional como a Suprema Corte da Argentina decidiram que a impunidade contraria tratados internacionais que vigoravam no país, dando destaque ao direito internacional. Naquele país, onde os militares mandaram entre 1976 e 1983, estima-se que pelo menos 30 mil pessoas tenham sido mortas ou tenham desaparecido. Desde a volta da democracia 515 pessoas foram condenadas por crimes cometidos durante o regime militar. O próprio general Jorge Rafael Videla, governante do país durante os "anos de chumbo" na Argentina foi condenado à prisão perpétua e morreu na cadeia em 2013, aos 87 anos.

Esse caminho, como visto, foi seguido pelo Chile e Uruguai que iniciaram tardiamente processos penais contra agentes das ditaduras.

Seguindo o modelo da América Latina de Comissões da Verdade, na África do Sul, a Comissão da Verdade e Reconciliação CVR teve como principais objetivos evitar o esquecimento oficial dos fatos, promovendo processos de confissão e de desculpas, condic,ão para a obtenção de indulto, caracterizando-se, assim, a CVR como medida de autorresponsabilização. Assim, a CVR inovou em relação às Comissões da Verdade instituídas na América Latina ao ouvir vítimas e militares, além de tornar públicas estas experiencias, as quais causaram grande impacto na sociedade.

No Brasil prevaleceu por décadas a opção política de "esquecer" a repressão dos opositores durante a ditadura militar, instalada após o golpe de 1964. No final da ditadura, a Lei no 6.683 de 1979 anistiou a maioria dos crimes de natureza política cometidos durante o regime. Os Tribunais consideraram que essa lei beneficiava tanto os opositores como os agentes da ditadura. Por isso ninguém foi condenado após o fim da ditadura. 
Artigo original

Hegemonia - Revista Eletrônica de Relações Internacionais do Centro Universitário Unieuro

ISSN: $1809-1261$

UNIEURO, Brasília, número 15, 2015, pp. 42-92.

Nos últimos anos a validade e a interpretação da Lei de Anistia foi duramente questionada. Organizações de vítimas da perseguição política e grupos de esquerda pediram o esclarecimento de fatos ocorridos durante a ditadura (direito à verdade) e a identificação dos responsáveis por crimes estatais e suas responsabilizações penais (direito à justiça).

O Governo Federal acenou com uma posição dúbia. Por um lado, indenizou vítimas do regime e publicou uma ampla pesquisa sobre os acontecimentos e as vítimas da ditadura. O último passo nessa direção foi a criação da Comissão Nacional da Verdade, instalada em 2012 com a principal tarefa de esclarecer graves violações de direitos humanos durante a ditadura. Por outro lado, o governo quis evitar conflitos com grupos de militares que não admitem questionamentos da atuação das forças de segurança durante a ditadura. Muitos acontecimentos do período são ainda considerados "segredo de Estado". Um exemplo é a não informação dos familiares dos envolvidos na guerrilha do Araguaia sobre o ocorrido com os "desaparecidos".

Tramitam nesse momento ações de familiares de vítimas e do Ministério Público Federal com a finalidade de conseguir a abertura de arquivos estatais, de identificar os responsáveis pelos crimes da ditadura, de indenizar as vítimas e de perseguir penalmente agentes da ditadura por atos que, segundo alguns entendimentos não prescrevera ainda.

A questão foi levada ao Supremo Tribunal Federal que julgou em 2010 a Arguição de Descumprimento de Preceito Fundamental 153, confirmando a validade da Lei de Anistia.Alguns meses depois a Corte Interamericana de Direitos Humanos, julgando o caso 11.552, condenou o Brasil pela sua inércia em perseguir os responsáveis da ditadura e pela falta de esclarecimento dos acontecimentos durante o período. A mesma sentença declarou a invalidade da lei de anistia na parte que beneficia a criminalidade estatal. Essas decisões contrárias criaram um impasse político, ainda que, do ponto de vista legal, a decisão do STF é vinculante para todos no Brasil. 
Artigo original

Hegemonia - Revista Eletrônica de Relações Internacionais do Centro Universitário Unieuro

ISSN: $1809-1261$

UNIEURO, Brasília, número 15, 2015, pp. 42-92.

O relator da ação foi o então ministro Eros Grau, um exmilitante do $P C$ do $B$ e também um dos muitos que sentiu de perto o peso da ditadura, ao ser preso e torturado no ano de 1972. Foi dele um dos 7 votos favoráveis à constitucionalidade da Lei da Anistia. Outro ministro que ratificou a anistia aos agentes do Estado foi Cezar Peluso, afirmando que a Lei da Anistia era fruto de um acordo com "legitimidade política e social" e de um momento histórico em que o Brasil fizer uma "opção a caminho da concórdia".

O Brasil tomou o mesmo rumo trilhado pela Espanha, país que optou por entabular um pacto com a sociedade a fim de garantir a transição de forma democrática na década de 1970, deixando impunes os atos de violação aos direitos humanos praticados durante o regime ditatorial de Francisco Franco, que governou de 1935 a 1975, ano de sua morte.

A decisão política de perdoar os crimes cometidos durante 0 regime militar no Brasil permitiu, por meio da Lei de Anistia, a libertação de milhares de presos políticos, bem como a volta de centenas de exilados e, ainda, garantiu que as pessoas atingidas pelos draconianos atos institucionais pudessem se reintegrar à vida política do país. Por outro lado, renegou à sociedade um requisito necessário para a reconciliação, qual seja, a justiça, uma vez que no bolsão anistiado também foram inseridos os torturadores e homicidas a serviço do Estado ditatorial.

Em 1995, durante o governo de Fernando Henrique Cardozo, um novo passo foi trilhado com a criação da Comissão Especial de Mortos e Desaparecidos. Sua principal missão era promover o reconhecimento da responsabilidade do Estado por mortes e desaparecimentos ocorridos durante a ditadura e pagar indenizações às famílias das vítimas, tendo inclusive ido além, esclarecendo as circunstâncias de diversos casos de mortes e desaparecimentos, com a realização de novas perícias e localização de documentos esquecidos em arquivos públicos. 
Artigo original

Hegemonia - Revista Eletrônica de Relações Internacionais do Centro Universitário Unieuro

ISSN: $1809-1261$

UNIEURO, Brasília, número 15, 2015, pp. 42-92.

Em 2002 o processo de reparação foi ampliado quando o governo Lula decidiu pagar compensações financeiras a todos que tivessem sofrido perseguições e violências durante o regime militar, e não só a familiares de mortos e desaparecidos.

A partir de 2010, procuradores do Ministério Público Federal apresentaram pedidos de investigações sobre crimes da ditadura. A tese encampada é de que esses crimes, tais como o sequestro de militantes até hoje desaparecidos, têm caráter permanente, e por isso seus autores não podem ser beneficiados pela Lei da Anistia. Oito ações foram propostas contra 17 pessoas. Entretanto, embora haja decisões favoráveis de juízes de primeira instância, essas condenações têm sido reformadas nas instâncias de segundo grau e Superiores.

No dia 18 de dezembro de 2013, um gesto simbólico reitera a tentativa de caminhar em prol da Reconciliação. Nessa data o Congresso Nacional devolveu o mandato do Presidente João Goulart, deposto pelo golpe de 1964. Impende ressaltar que, enquanto a maioria dos presentes aplaudiam evasivamente quando a Presidenta Dilma Rousseff passou às mãos de João Vicente Goulart, filho de Jango, o diploma do pai, os representantes das Forças Armadas no evento, o general Enzo Peri, o brigadeiro Juniti Saito e o almirante Julio Soares, permaneceram inertes, destoando da massa eufórica.

Esse detalhe parece ser demonstrativo da dificuldade existente até hoje em lidar com a memória, reparação e justiça quanto aos graves desrespeitos aos direitos humanos praticados ao longo do regime militar no Brasil. Enquanto países como a Argentina e o Chile estimularam com a restauração da democracia as desculpas proferidas por oficiais de alto escalão pelos erros do passado, abrindo caminho para investigações e punições, no Brasil isso ainda não ocorreu.

A Lei da Anistia foi aprovada pouco depois da posse do último presidente militar, João Baptista Figueiredo e foi importante para conter as pressões que a ala mais radical da caserna que fazia na 
Artigo original

Hegemonia - Revista Eletrônica de Relações Internacionais do Centro Universitário Unieuro

ISSN: $1809-1261$

UNIEURO, Brasília, número 15, 2015, pp. 42-92.

época contra o projeto de abertura política do governo, entretanto, criou também um desequilíbrio ao garantir que os militares nunca seriam julgados por seus crimes, ao contrário dos anistiados que, em sua grande maioria, já haviam sido presos e processados pela ditadura.

Não se pode deixar de considerar que as circunstâncias em que a Lei da Anistia surgiu diminuem sensivelmente sua legitimidade. $O$ contexto, 1979, em pleno regime militar, leva à sugerir uma "autoanistia", tão somente aceita goela abaixo por ser o único meio possível para encerrar a longeva ditadura.

Há esperança de que em um cenário não muito distante, o Brasil possa finalmente completar sua Justiça de Transição, angariando $o$ requisito que lhe falta: a justiça com a responsabilização judicial dos agentes estatais que torturaram e mataram durante a ditadura. 0 desconforto criado por uma decisão da Corte Interamericana de direitos Humanos, ligada à Organização dos Estados Americanos (OEA), em dezembro de 2010, que condenou - Brasil pela morte dos guerrilheiros do Araguaia e determinou ao país que punisse os responsáveis calou fundo em boa parte da sociedade brasileira.

As recentes ações impetradas pelo Ministério Público Federal, como dito, são consequência dessa tentativa de se avançar na Justiça de Transição brasileira. Hoje, entretanto, o Brasil continua devedor de uma Justiça de Transição efetivamente completa, contendo todos os seus principais requisitos: memória, verdade e justiça. Este último, relegado, obrigando os familiares e amigos das vítimas de torturas, desaparecimentos forçados e assassinatos, a uma punição que nunca tem fim, qual seja, a sensação de impunidade e de descaso aos mais fundamentais direitos humanos.

BIBLIOGRAFIA 
Artigo original

Hegemonia - Revista Eletrônica de Relações Internacionais do Centro Universitário Unieuro

ISSN: $1809-1261$

UNIEURO, Brasília, número 15, 2015, pp. 42-92.

ABRÃO, Paulo; TORELLY, Marcelo D. (Org.) Justiça de Transição no Brasil: a dimensão da reparação. Repressão e Memória Política no Contexto Ibero-Brasileiro: estudos sobre Brasil, Guatemala, Moçambique, Peru e Portugal. Brasília: Ministério da Justiça, Comissão de Anistia; Portugal: Universidade de Coimbra, Centro de Estudos Sociais. 2010.

BOBBIO, N. A era dos Direitos. São Paulo. Ed. Campus. ; MATTEUCI, Nicola; Gianfranco, PASQUINO. Dicionário de política. 7a Ed. V. 2. Brasília: UNB, 1995.

BRANDÃO, Helena Hathsue Nagamine. Introdução à análise do discurso. $3^{a}$ Ed. Campinas, SP. Ed. Unicamp, 2013.

BRASIL. Constituição (1998). Constituição da República Federativa do Brasil. Brasília, DF: Senado Federal, Centro Gráfico, 1998.

CANO, Ignacio. 2012. "Nas trincheiras do método: o ensino da metodologia das ciencias sociais no Brasil." In:Sociologias, Porto Alegre, ano 14, n. 31, set/dez. 2012.

GASPARI, Elio. A ditadura escancarada. São Paulo: Companhia das Letras, 2002.

GORENDER, Jacob. Direitos Humanos - O que são?(ou devem ser?). São Paulo. Editora Senac, 2004.

HALBWARCHS, Maurice. A memória coletiva. Traduzido por Laurent León Schaffter, Paris: Presses Universitaires de France. 1950.

LEAL, Rogério Gesta. Verdade, Memória e Justiça: um debate necessário. Santa Cruz do Sul: EDUNISC. 2012.

MARROU, H. I. História da Educação na Antiguidade. São Paulo: EPU, 1990.

PINTO, Simone Martins Rodrigues. Memória, Verdade e Responsabilização. Brasília. Editora UNB. 2012. 
Artigo original

Hegemonia - Revista Eletrônica de Relações Internacionais do Centro Universitário Unieuro

ISSN: $1809-1261$

UNIEURO, Brasília, número 15, 2015, pp. 42-92.

PINTO, Céli Regina Jardim. Elementos para uma análise de discurso político. Barbarói (Revista do Departamento de Ciências Humanas e do Departamento de Psicologia da Universidade de Santa Cruz do Sul), vol. 24, n. 1, 2006.

PIOVESAN, Flávia; SOARES, Inês Virginia Prado (coords.). Direito ao Desenvolvimento. São Paulo: Fórum, 2010

PIOVESAN, Flávia. Temas de Direitos Humanos. São Paulo. Ed. Saraiva. 2012.

QUINALHA, Renan Honório. Justiça de Transição: contornos do conceito. São Paulo. Dobra Editorial. 2013.

SANTOS, Cecília MacDowell. Questões de Justiça de Transição: a mobilização dos direitos humanos e a memória da ditadura no Brasil. In: Repressão e Memória Política no Contexto Ibero-Brasileiro: estudos sobre Brasil, Guatemala, Moçambique, Peru e Portugal. Brasília: Ministério da Justiça, Comissão de Anistia; Portugal: Universidade de Coimbra, Centro de Estudos Sociais, 2010.

SARLET, Ingo Wolfgand. A Eficácia dos direitos fundamentais. 6. ed. rev. atual. e ampl. Porto Alegre: Livraria do Advogado, 2006.

SARTORI, Giovanni. A Teoria da Democracia Revisitada. São Paulo: Editora Ática, 2004.

TORELLY, Marcelo D. Justiça de Transição e Estado Constitucional de Direito. Belo Horizonte, Fórum, 2012.

VENTURA, Zuenir. 1968: o Ano que Não Terminou. Editora Nova Fronteira. 2006. 